Solid Earth Discuss., https://doi.org/10.5194/se-2017-142

Manuscript under review for journal Solid Earth

Discussion started: 30 January 2018

(c) Author(s) 2018. CC BY 4.0 License.

\title{
3D numerical modelling of the re-distribution of partially molten lower crust rocks in relay zones between faults during transtension: Implications for the Sefwi terrane, SW Ghana
}

Xiaojun Feng ${ }^{1,2,3^{*}}$, Enyuan Wang ${ }^{1,2}$, Jérôme Ganne ${ }^{3}$, Roland Martin ${ }^{3}$, Mark W. Jessell ${ }^{3,4}$

$5 \quad{ }^{1}$ Key Laboratory of Gas and Fire Control for Coal Mines, China University of mining and Technology, Ministry of Education, Xuzhou, 221116, China

${ }^{2}$ School of Safety Engineering, China University of Mining and Technology, Xuzhou, 221116, China

${ }^{3}$ Geosciences Environnement Toulouse, Observatoire Midi Pyrénées, Toulouse, 31400, France

${ }^{4}$ Centre for Exploration Targeting, The University of Western Australia, Perth, WA 6009, Australia

Correspondence to: Xiaojun.Feng (xiaojun.feng@cumt.edu.cn; fxjuncumt@gmail.com)

\begin{abstract}
High-grade tectono-metamorphic domains in the Sefwi terrane of Ghana are separated from adjacent low-grade greenstone belts by two main shear zones. The high-grade rocks are thought to have been exhumed along sinistral shear zones during the D2 ENE-WSW transtension. To better understand the role boundary conditions and the spatial relationship of faults play in the re-distribution of partially molten lower crust, ten 3D thermo-mechanical models have been constructed.

15 The results show that the normal component of velocity boundary conditions mainly controls the exhumation of the lower crust which occurred along pre-existing faults, while the exhumation in the relay zones between faults is controlled by the ratio of extension rate to shear rate applied at the boundaries. The strike of the exhumation belt made of partially molten lower crust rocks in the relay zone is sub-orthogonal to the transtension direction. The isostatic compensation from lowdensity upper mantle to overlying crust (thinning) is higher under transtension than under extension.
\end{abstract}

The lower crust exhumation influenced by inherited shear zones can be used to better understand the loci of the high-grade rocks in the Sefwi terrane. We suggest that the Kukuom-Juaboso domain composed of up to amphibolite-migmatite facies probably resulted from the concentration of partially molten rocks in the relay zone between the Ketesso and Kenyase shear zones during the D2 ENE-WSW transtension. The two shear zones probably underwent two main stages for growth and 25 maturation from the D1 to D2 deformation phases. The regional exhumation of the high-grade rocks in the Sefwi terrane probably occurred within a duration of less than $5 \mathrm{Ma}$.

\section{Introduction}

Pre-existing faults commonly act as preferentially re-activated sites when external boundary conditions change (Chester et al., 1991; Beekman et al., 1996), and play a dominant role in concentrating high strain (Morley et al., 2004) through 
Solid Earth Discuss., https://doi.org/10.5194/se-2017-142

Manuscript under review for journal Solid Earth

Discussion started: 30 January 2018

(c) Author(s) 2018. CC BY 4.0 License.

geological time. A regional-scale fault commonly originates from a network of local pre-existing discontinuities (Feng et al., 2016b), through which fracture propagation of their surrounding rocks will be inhibited (Teufel and Clark, 1984; Morley, 1999). With respect to an interacting strike-slip fault system, both soft and hard linkages are commonly involved. During the growth and propagation of faults, a soft linkage can mature to a hard linkage via fracture propagation at the tips of faults and

5 repeated interaction between faults (Gupta and Scholz, 2000; Pachell and Evans, 2002; Kim et al., 2005).

The emplacement of partially molten rocks is dominantly driven by the contrasts in density and viscosity compared to surrounding solid rocks (Brown, 1994; Petford et al., 2000). Pre-existing faults are thought to play an important role in influencing and promoting the processes of the emplacement (Neves et al., 1996; Koyi and Skelton, 2001; Weinberg et al.,

10 2006; Tirel et al., 2008). For extension-dominated regional exhumation of the lower crust, Feng et al. (2017) demonstrated that the orientation of pre-existing faults largely controls the rate and distribution of lower crust exhumation using 2D and 3D thermo-mechanical models. The influence of pre-existing faults on the formation process of metamorphic core complexes (MCCs) during extension has also been explored in analogue models (Brun et al., 1994, Koyi and Skelton, 2001), and the structural evolution coincides well with numerical results (Tirel et al., 2008; Rey et al., 2009a, 2009b, 2011; Feng et

15 al., 2017).

The growth of a fault system under transtensional boundary conditions has been widely studied (Luyendyk, 1991; Dewey et al., 1998; Fossen and Tikoff, 1998; Lin et al., 1998; Dooley and Schreurs, 2012). Furthermore, the exhumation of high grade rocks simulated by numerical and analogue models has been also explored under compressional (Lin et al., 2000; Burov et

20 al., 2001; Seyferth and Henk, 2004; Ganne et al., 2014) and extensional (Brun et al., 1994; Rey et al., 2009a, 2009b, 2011; Le Pourhiet et al., 2012; Feng et al., 2018) boundary conditions. However, 3D numerical models including the processes of fault growth and lower crust exhumation driven by transtension boundary conditions have still not been completely explored.

The Sefwi terrane of SW Ghana is mainly composed of the North-Western Sunyani basin, the South-Eastern Kumasi basin and the central high-grade Kukuom-Juaboso domain (KJD). The KJD domain is bounded by two main shear zones: the Kenyase shear zones to the Northwest and the Ketesso shear zones to the Southeast. To better understand how these two shear zones influence the regional exhumation of the partially molten lower crustal rocks during the D2 transtensional deformation stage, ten 3D thermo-mechanical models have been constructed. The models are constrained by the metamorphic rock records within the study area and structural interpretation performed by McFarlane et al. (2016, 2017) and

30 Jessell et al. (2012). This study may shed light on the role high strain zones play in re-distribution of partially molten lower crust rocks under transtension boundary conditions, as well as on the evolution of structures and deformation in the Sefwi terrane during the Eburnean Orogeny (ca. 2.2-2.0Ga). 
Solid Earth Discuss., https://doi.org/10.5194/se-2017-142

Manuscript under review for journal Solid Earth

Discussion started: 30 January 2018

(c) Author(s) 2018. CC BY 4.0 License.

\section{Geological setting}

The Leo-Man Craton (Figure 1) is the southernmost segment of the West African Craton (WAC). It is composed of the Eastern Paleoproterozoic Baoulé-Mossi (BM) domain and the South-Western Archaean Kénéma-Man (KM) domain. These two domains are separated by the Sassandra Fault (SF). The KM domain consists of the oldest rock (gneisses) in the WAC, ranging between 3600 and 3500Ma (Rollinson, 2016). The ages of major rocks range between 3026 and 2850Ma. This domain was mainly intruded by two episodic magmatic pules, one between 3260 and 3050Ma and the other between 2960 and $2850 \mathrm{Ma}$ (Rollinson, 2016). The BM domain consists of extensively distributed N-S trending greenstone-granitoid belts (Figure 1b). The intruded granitoids in the BM domain locally yield ages between 2195 and 2172Ma (Hirdes et al., 1992; Baratoux et al., 2011; Sakyi et al., 2014). Several generations of main magmatic pulses took place later, ranging between

102153 and 2068 Ma (Hirdes et al., 1996; Egal et al., 2002; Gasquet et al., 2003; Baratoux et al., 2011; Block et al., 2015).

The Sefwi-Sunyani-Comoé region (Figure 1b, outlined by red box) is in South-Western Ghana and the Ivory Coast, and consists of several sub-parallel NE-SW trending greenstone belts. The Sunyani and Kumasi basins (Figure 2) is mainly comprised of volcaniclastics, wackes and argillites (Leube et al., 1990). The two basins were intruded by numerous

15 granitoids with crystallization ages of $2088 \pm 1 \mathrm{Ma}$ for the Sunyani basin and $2116 \pm 2 \mathrm{Ma}$ for the Kumasi basin, respectively (U/Pb zircon dating, Hirdes et al., 1992). The Sefwi greenstone belt is composed of metamorphosed tholeiitic lavas, volcanoclastic and granitoids (Agyei duodu et al., 2009). The intruded granitoids within the belt yield ages of about 21802170Ma (Hirdes et al., 1992).

20 The KJD high grade tectono-metamorphic domain of up to amphibolite-migmatite facies is bounded by the Kenyase and Ketesso shear zones (Figure 2). The NE-trending Kenyase shear zones mark the boundary between the KJD high grade domain and the Sunyani basin. The NE-trending Ketesso shear zones cross through the Sefwi terrane. They separate lower grade domains of greenschist to non-metamorphosed facies in the Kumasi Basin from high grade domains in the Sefwi belt (Feybesse et al., 2006). According to the metamorphic results and structural interpretation performed for the Sefwi terrane by

25 McFarlane et al. (2016), the D1 tectono-metamorphic event contributing to crustal thickening buried crustal rocks up to 10$12 \mathrm{kbar}$ (corresponding to a buried depth of about $30-40 \mathrm{~km}$ ) and $700-800{ }^{\circ} \mathrm{C}$. The $\mathrm{D} 2$ deformation phase was a decompressional stage that took place at about $2073 \mathrm{Ma}$ (McFarlane et al., 2016), through which P-T values decreased to 7$8 \mathrm{kbar}$ (corresponding to a buried depth of about $20-25 \mathrm{~km}$ ) and $650-700{ }^{\circ} \mathrm{C}$, respectively.

\section{Method and model setup}

30 The exhumation of lower crust is simulated in a 3D Cartesian geometry using a visco-plastic rheology with the numerical code Underworld (Moresi et al., 2003, 2007). The code uses a Lagrangian PIC finite element scheme. The governing mass, 
Solid Earth Discuss., https://doi.org/10.5194/se-2017-142

Manuscript under review for journal Solid Earth

Discussion started: 30 January 2018

(c) Author(s) 2018. CC BY 4.0 License.

momentum and energy conservation equations are solved under the Underworld standard modelling framework, which is expressed as follows (Moresi et al., 2003, 2007):

$\frac{\partial \sigma_{i j}}{\partial x_{j}}=\rho_{e f f} \cdot g_{i}$

$\nabla \cdot u=0$

$\frac{\partial T}{\partial t}+u \cdot(\nabla T)=k \nabla^{2} T+\frac{H}{C p}-\frac{l h}{C p} \cdot \frac{\partial M}{\partial t}$

where $\sigma_{i j}$ is the Cauchy stress tensor, $g_{i}$ is the gravitational acceleration, $\rho_{\text {eff }}$ is the effective density, $u$ is the velocity, $\mathrm{k}$ is the thermal diffusivity, $\mathrm{H}$ is the radiogenic heat production per mass unit, $\mathrm{Cp}$ is the heat capacity, $\mathrm{lh}$ is the latent heat of

5 fusion and $\mathrm{M}$ is the melt fraction.

The 3D model domain is $300 \mathrm{~km}$ long (x direction), 140km wide (y direction) and $60 \mathrm{~km}$ thick (z direction), and modelled with a resolution of $2 \mathrm{~km} \times 2 \mathrm{~km} \mathrm{x} 1 \mathrm{~km}$ (Figure 3). The model is comprised of $16 \mathrm{~km}$ thick upper volcano-sediment, $16 \mathrm{~km}$ thick middle crust (mafic), $10 \mathrm{~km}$ thick lower crust and $18 \mathrm{~km}$ thick upper mantle (from top to bottom, Figure 3 ). In the 10 sedimentary and middle crustal domains, two vertical faults are placed in parallel. To explore the role that spatial relationship of pre-existing faults plays in the exhumation of the lower crust, two different patterns of fault system (with or without an overlapping zone between faults, corresponding to Model A and Model B shown in Figure 3) are tested in this study. According to the ratio of extension rate to shear rate applied on the boundaries, ten 3D thermo-mechanical models are designed for test cases (detailed parameters about the boundary conditions are listed in Tables 1 and 2).

15

Under the PIC finite element frame of the code Underworld, 30 particles are initialized in each cell. To show the exhumation of the lower crust and the compensation from the upper mantle to the overlying crust (crustal thinning during extension), we therefore employ 450 passive particles to trace the changes of position and vertical velocity during transtension (extension). The particles are divided into two groups: one placed in the upper surface of the lower crust $(\mathrm{Z}=-32 \mathrm{~km})$ and the other one placed in the upper surface of the upper mantle $(Z=-42 \mathrm{~km})$.

The mechanical boundaries are constrained by transtension (or extension) with YY-directed periodic boundary conditions (Figure 3). The bottom of the model is modelled with a free-slip boundary. The surface of the model is a free surface and its boundary thus directly corresponds to the topography (Moresi et al., 2003; Feng et al., 2016a). To balance the volume reduction due to applied extension rate, the upper mantle is allowed to flow in with a normal velocity during extension/transtension (Liao and Gerya, 2014; Ganne et al., 2014). With respect to the constraints on thermal boundary conditions, we here model the extension and transtension of a "hot" lithosphere, with a Moho temperature of $840{ }^{\circ} \mathrm{C}$. We use fixed temperatures of $0{ }^{\circ} \mathrm{C}$ for the model surface and $1200{ }^{\circ} \mathrm{C}$ for the base of the model, assuming a fixed temperature 
Solid Earth Discuss., https://doi.org/10.5194/se-2017-142

Manuscript under review for journal Solid Earth

Discussion started: 30 January 2018

(c) Author(s) 2018. CC BY 4.0 License.

gradient of $20^{\circ} \mathrm{C} / \mathrm{km}$. The solid-deformation behaviour is modelled with a depth-dependent yielding criterion (Drucker and Prager, 2013), which is expressed as follows (Moresi et al., 2007; Sharples et al., 2015):

$\tau_{I I}=\delta_{c}+P \cdot \tan \varphi$

where $\tau_{-}$II is the second invariant of the deviatoric stress tensor, $\delta_{-} \mathrm{c}$ is the effective cohesion of rocks, $\mathrm{P}$ is the local pressure, $\tan \varphi$ is the effective friction coefficient of rocks. In the crustal domain, an initial cohesion value of $15 \mathrm{MPa}$ and an initial coefficient of internal friction angle of 0.3 are defined. The effective cohesion and coefficient of internal friction angle (drop to a maximum of $20 \%$, Rey et al., 2009b; Faulkner et al., 2010) is modelled by coupling with a strain weakening principle (Gueydan et al., 2014; Feng et al., 2016b). The cohesion and coefficient of internal friction angle of pre-existing faults are set to $10 \%$ of the initial values of the crust (Rey et al., 2009b).

According to the metamorphic modelling calculated by Ganne et al. (2014), the mafic crust rocks start to melt (from $1 \%$ to $30 \%$ ) at a solidus temperature of about $836^{\circ} \mathrm{C}$ (corresponding to a buried depth of about $42 \mathrm{~km}$ at the given temperature gradient of $20^{\circ} \mathrm{C} / \mathrm{km}$ ). In this study, the middle crust layer is placed between $Z=-16 \mathrm{~km}$ and $Z=-32 \mathrm{~km}$ (Figure 3, Table 3). Under extension (transtension) boundary conditions, the upper crust hardly melts. We therefore only allow the lower crust to

15 undergo partial melting process. We assume that the $T_{\text {sol }}$ and $T_{\text {liq }}$ temperatures of the lower crust do not change with pressure/depth (Gerya et al., 2008; Ganne, et al., 2014). To calculate the volumetric melt fraction $(M)$, the volumetric melting coefficient $\left(X_{M}\right)$ for calculating melt fraction $(M)$ is introduced as follows (Gerya and Yuen, 2003; Gerya and Burg, 2007; Gerya et al., 2008):

$X_{M}=0$

$$
\begin{aligned}
& \text { at } T \leq T_{\text {sol }} \\
& \text { at } T_{\text {sol }}<T<T_{\text {liq }} \\
& \text { at } T \geq T_{\text {liq }}
\end{aligned}
$$$$
X_{M}=\frac{T-T_{\text {sol }}}{T_{\text {liq }}-T_{\text {sol }}}
$$$$
X_{M}=1
$$

where $T_{\text {sol }}$ and $T_{l i q}$ represent the wet solidus and dry liquidus temperatures of the lower crust, respectively.

20 We assume that the volumetric melt fraction $(M)$ increases linearly, when the temperature is above the wet solidus temperature and below the dry liquidus temperature (Gerya et al., 2008; Ganne et al., 2014).

$M=X_{M} \cdot M_{\max }$

In natural cases, the effective viscosity of partially molten rocks is usually $10^{3} \sim 10^{10}$ times lower than their surrounding

25 solid rocks (Vanderhaeghe, 2001). In our models, when the local temperature reaches the melting point of the lower crust $\left(T_{\text {sol }}\right)$, we model the effective viscosity by using a function of melt fraction $(M)$ (Pinkerton and Stevenson, 1992):

$\eta_{\text {eff }}=5 \times 10^{16} \cdot \exp \left(2.5+(1-M)\left(\frac{1-M}{M}\right)^{0.48}\right)$ 
Solid Earth Discuss., https://doi.org/10.5194/se-2017-142

Manuscript under review for journal Solid Earth

Discussion started: 30 January 2018

(c) Author(s) 2018. CC BY 4.0 License.

The effective density in the model domain is calculated according to the local temperature, the thermal expansion coefficient $(\alpha)$ of $3 \cdot 10^{-5} \mathrm{~K}-1$ and the melt fraction $(\mathrm{M})$. For rocks which cannot melt, a linear relationship used for calculating effective density is expressed as equation (8). For the lower crust layer, the effective density is calculated by equation (9), which is similar to the equations employed in Rey et al. (2009b):

$\rho_{\text {eff }}=\rho\left[1-\alpha \cdot\left(T-T_{0}\right)\right]$

$\rho_{\text {eff }}=\rho\left[1-\alpha \cdot\left(T-T_{0}\right)-\beta \cdot M\right]$

5 where $\rho_{e f f}$ is the effective density, $\beta$ is the coefficient of thermal expansion, $T$ is the local temperature, $T_{0}$ is the reference temperature at surface $\left(0{ }^{\circ} \mathrm{C}\right), \beta$ is the coefficient of expansion related to phase change (Rey et al., 2009b).

\section{Results}

We have constructed ten 3D thermo-mechanical models (with two classes, Model A and five Model B, with detailed parameters about the boundary conditions can be found in Table 1 and Figure 3) to explore the influence of pre-existing

10 faults on re-distribution of partially molten lower crust during extension and transtension. All simulations were run in parallel on the EOS cluster machine in Toulouse, France (https://www.calmip.univ-toulouse.fr/).

\subsection{The upper surface of the partially molten lower crust}

Initially, we applied a fixed extension rate of 2cm/year on the boundaries for experiments A1 and B1 (Figures 4A1 and 4B1). The results show that the partially molten lower crust rocks concentrate preferentially along pre-existing faults during

15 extension. In the relay zone between faults, the concentration of the partially molten lower crustal materials is much lower than that along the faults. Comparing cases A1 with B1, the focus of exhumation in relay zones between faults in case A1 is higher than that in case B1.

In experiments A2 and B2, a tangential component of velocity boundary conditions was additionally introduced into the fault

20 system. The ratio of extension rate to shear rate applied on the boundaries was set to 2, which means that this fault system is still dominated by the applied normal component of velocity boundary conditions. For case A2 (Figure 4A2), the partially molten lower crust rocks move towards the faults and their overlapping zone, leading to the formation of a rising belt (red in Figure 4A2, reaching about $10 \mathrm{~km}$ of uplift) made of partially molten rocks. While case B2 (Figure 4B2) only shows a high concentration of the partially molten lower crust rocks along the faults. At about $0.88 \mathrm{Ma}$, the upper surface of the partially molten lower crust in case B2 reaches about $10 \mathrm{~km}$ of uplift along the faults and only 5-7 km of uplift in their relay zone.

In experiments $\mathrm{A} 3$ and B3, we further increased the shear rate in the fault system, making it equal to extension rate applied on boundaries. Case A3 (Figure 4A3) shows that a high concentration of the lower crust exhumation is observed both along 
Solid Earth Discuss., https://doi.org/10.5194/se-2017-142

Manuscript under review for journal Solid Earth

Discussion started: 30 January 2018

(c) Author(s) 2018. CC BY 4.0 License.

the faults and in the relay zone between faults. Compared to case A2, the relay zone in case A3 concentrates much more partially molten rocks. Regarding the exhumation along the faults in case B3 (Figure 4B3), which shows a very similar distribution of the lower crust with cases B1 and B2. While the exhumation occurred around the relay zone in case B3, it is largely increased compared to cases B1 and B2. The difference in the distribution of the lower crust exhumation indicates that increasing the shear rate to the value of extension rate applied can enhance the concentration of the partially molten lower crust in the relay zone between faults during transtension.

Further increasing the shear rate in experiments A4 and B4 (making the ratio of extension rate to shear rate equal to 0.5) results in the tangential component of velocity boundary conditions becomes dominant in the fault system. Case A4 shows that the branch of the red exhumation belt located into the relay zone is wider than its other red branches along the faults (Figure 4A4). Regarding case B4 (Figure 4B4), it shows that the distribution of the lower crust exhumation is similar to case B3. Highly concentrated partially molten rocks in the relay zone link the uplifted partially molten rocks along the faults.

In experiments $\mathrm{A} 5$ and $\mathrm{B} 5$, the ratio of extension rate to shear rate applied on boundaries was decreased to 0.25 , and the 15 tangential component of velocity boundary conditions dominates compared to other experiments (A1-A4, B1-B4). The results show that the distribution of the exhumation in cases A5 and B5 is characterized by a relatively high concentration of partially molten lower crust rocks along two parallel high strain zones and a relatively low concentration of the exhumation in the relay zone. The two parallel high strain zones originated from the two pre-existing faults become well developed and matured during transtension (white dotted lines in Figures 4A5 and 4B5).

Comparing all the experiments, the results show that the normal component of velocity boundary conditions generally controls the exhumation of the partially molten rocks occurred along faults, while the exhumation of the lower crust in the relay zone between faults is pre-dominated by the ratio of extension rate to shear rate applied on boundaries. With respect to the exhumation of the lower crust occurred in the relay zone between faults, its concentration generally increases with the decreasing ratio of extension rate to shear rate to an extent (experiments A1-A4 and B1-B4).

\subsection{Surface relief}

At a crustal scale, the processes of faulting and lower crust exhumation both play an important role in shaping surface relief (D’Agostino et al., 1998; Feng et al., 2016a). In an extensional setting (Figures 5A1 and 5B1), the relay zone between faults in case A1 shows a subsidence of about $1-1.5 \mathrm{~km}$, while in case B1 it shows about $2 \mathrm{~km}$ of uplift at $0.85 \mathrm{Ma}$.

In transtension, experiments A2-A4 show a generally similar distribution of relief with each other (Figure 5A2, 5A3 and 5A4). Subsidence (green colour) mainly focus along faults and in the relay zone between faults, resulting in forming a continuous subsidence belt. The width of the subsidence belt in the relay zone increases with the decreasing ratio of 
Solid Earth Discuss., https://doi.org/10.5194/se-2017-142

Manuscript under review for journal Solid Earth

Discussion started: 30 January 2018

(c) Author(s) 2018. CC BY 4.0 License.

extension rate to shear rate applied (the ratio decreases by the order: A1-A2-A3-A4). Regarding the distribution of uplift, cases A1 and A2 show a highly concentrated uplift along the South-Eastern and North-Western edges of the subsidence region. The uplifted region observed in experiments A3 and A4 also focus along the edges of the subsidence belts, but it distributes in a generally even fashion compared to experiments A1 and A2. For experiments B1-B4, the subsidence region

5 in the relay zone between faults widens with the decreasing ratio of extension rate to shear rate (from experiments B1 to B4), while the distribution of the uplifted region is similar with each other.

Experiments A5 and B5 were designed to have a ratio of 0.25 (extension rate to shear rate). This indicates that the fault system is dominated by the tangential component of velocity boundary conditions. Two subsidence belts are observed along

10 the strike of pre-existing faults, yielding a subsidence of about $1.5-2 \mathrm{~km}$ at $1.5 \mathrm{Ma}$. The uplifted regions are observed mainly between the two subsidence belts, as well as slightly along the external boundaries of the subsidence belts. In experiment A5, the uplifted region between the two subsidence belts shows a step form (Figure 5A5), while in Experiment B5 it displays a linear distribution (Figure 5B5). The two experiments yield a similar uplift of about $2 \mathrm{~km}$.

\subsection{Particles motion: extension versus transtension}

15 Here, to compare and quantify the effect of boundary conditions on the lower crust exhumation and the compensation from the upper mantle to the overlying crust (crustal thinning during extension), two groups of passive particles are initialized (Figures 6 and 7) in the upper surfaces of the lower crust and the upper mantle, respectively.

In extension (experiment B1, Table 1), no significant exhumation (Figure 6) is observed prior to 0.25Ma, and the 20 compensation from the upper mantle to the overlying crust is not remarkable, either. At about $0.85 \mathrm{Ma}$, a maximum uplift of about $10 \mathrm{~km}$ (dark red in Figure 6) is recorded by the particles placed along faults, while the particles initialized in the relay zone between faults only show about $6 \mathrm{~km}$ of uplift (yellow to light orange colour in Figure 6). With respect to the deeper particles placed in the upper surface of the upper mantle, they yield a maximum uplift of about $6-7 \mathrm{~km}$, showing a similar distribution with the uplifted regions observed in the upper particles.

25

In transtension (experiment B3), all the particles integrally move and rotate with the applied tangential component of velocity boundary conditions (Figure 7). The distribution of uplift does not show significant difference compared to experiment B1 (extension) prior to about 0.47Ma. As transtension continues (at about 0.63Ma), the upper particles located in the relay zone between faults significantly exhume, yielding a height of about $7 \mathrm{~km}$. At about $0.84 \mathrm{Ma}$, the upper particles

30 record a maximum uplift of about $10 \mathrm{~km}$. With respect to the particles placed in the upper surface of the upper mantle, they show a relatively even distribution of uplift, yielding a height of about $8-9 \mathrm{~km}$ at $0.84 \mathrm{Ma}$. 
Solid Earth Discuss., https://doi.org/10.5194/se-2017-142

Manuscript under review for journal Solid Earth

Discussion started: 30 January 2018

(c) Author(s) 2018. CC BY 4.0 License.

\section{Discussion}

\subsection{Migration of particles: extension versus transtension}

In a system comprised of pre-existing faults and partially molten lower crustal rocks, the orientation of faults and boundary conditions are both thought to play an important role in influencing the distribution of lower crust exhumation (Rey et al.,

5 2009b). Feng et al. (2018) traced the upper and middle planes of lower crust using passive particles in extension. Their results show that the passive particles in the middle plane integrally move towards the intersection zones of pre-existing faults and largely contribute to regional exhumation.

The uplift observed on the deeper particles can be explained by the isostatical compensation from the lower density mantle

10 to the thinning part of overlying crust during transtension (Abers et al., 2002; Huet et al., 2011). The difference in uplift between the two planes of particles (the upper surfaces of the lower crust and the upper mantle) is about 3-4km under extension (case B1) and about 1-2km under transtension (case B3), respectively (Figures 6 and 7). The reason for forming such gap of uplift between the upper and lower planes of particles is probably due to (1) the partially molten rocks in the middle level of the lower crust significantly move towards the relay zone between faults, and make a significant contribution

15 to regional exhumation (Feng et al., 2018), (2) the upper mantle rocks are mechanically vigorous compared to the lower crust rocks (partially molten rocks) and they must show more resistance to deformation compared to the overlying partially molten lower crust (Feng et al., 2018) and display some lag to flow upward to compensate the thinning part of the overlying crust (Abers et al., 2002; Rey et al., 2011; Piccardo, 2016). This also indicates that, for experiment B1 controlled by extension, the partially molten lower crustal rocks in the middle level make a higher contribution to exhumation in the relay zone between

20 faults than that under transtension (experiment B3). In other words, the low-density upper mantle compensates much more the overlying crust in experiment B3 (transtension) compared to experiment B1 (extension). This inference is supported by the curves of the exhumation rate over time in Figures 8a and 9a (detailed discussions will be presented in following section 5.2).

25 According to the distribution of upwelling partially molten rocks observed in experiments B1 and B3, the regional exhumation of the lower crust along the faults does not show significant difference between the cases in extension and transtension. In the relay zone between faults, the tangential component of velocity boundary conditions plays an important role in allowing the concentration of partially molten lower crust rocks. The reason for focusing such high concentration of the partially molten rocks in the relay zone is probably due to the fact that the tangential component of velocity boundary

30 conditions can help produce linking damage/weak zones (Kim et al., 2004) around a strike-slip fault zone. The linking damage/weak zones evolve and become matured through the interaction between the tips of adjacent faults (Kim et al., 2001), undergoing a process from a soft linkage to a hard linkage. These damage/weak zones (in the relay zone between faults) could make a direct contribution to concentrating partially molten rocks during transtension (extension), this process could 
Solid Earth Discuss., https://doi.org/10.5194/se-2017-142

Manuscript under review for journal Solid Earth

Discussion started: 30 January 2018

(c) Author(s) 2018. CC BY 4.0 License.

be also indirectly assisted and enhanced by the removal of overburden in the relay zone (subsidence regions shown in Figure 5).

\subsection{Exhumation rate}

The exhumation rate of partially molten rocks in metamorphic core complexes (MCCs) can provide some stretching history

5 (Rey et al., 2009b). Here, we discuss the influence of the spatial relationship of faults and ratio of extension rate to shear rate applied on boundaries on exhumation rate of the partially molten lower crust rocks.

Figures $8 \mathrm{a}$ and 9a show the vertical velocity of a selected particle $((\mathrm{X}, \mathrm{Y}, \mathrm{Z}) /(70,150,-32) / \mathrm{km}$, see Figure 3) pertaining to the upper surface of the lower crust, which can be used to indicate the exhumation rate of the partially molten lower crustal materials during transtension (extension). During extension/transtension, rocks can be transferred from the underlying lowdensity mantle to the overlying crust (crustal thinning) due to isostatic unbalance, this is referred to a compensation process (Banks et al., 1977; Banks and Swain, 1978). Figures 8b and 9b present the vertical velocity of a passive particle ((X, Y, Z) / $(70,150,-42) / \mathrm{km}$, see Figure 3) initialized in the upper surface of the upper mantle, which can be employed to quantify the compensated process occurred in the relay zone between faults.

15

For Model A and Model B (including ten experiments according to the ratio of extension rate to shear rate applied on boundaries), the compensation rate from the upper mantle to the overlying crust generally shows a similar trend with the exhumation rate of the lower crust (Figures 8 and 9). At the ratio of 1 (extension rate equals to shear rate), the maximum rate of the lower crust exhumation is observed in the relay zone between faults, as well as the maximum compensation rate from

20 the upper mantle to the overlying crust. When the ratio of extension rate to shear rate was set to 0.25 , indicating a predominantly simple shear fault system, the lowest rates of the exhumation and the compensation are recorded in the relay zone.

In terms of the influence of spatial relationship of pre-existing faults on the lower crust exhumation and the compensation from the upper mantle to the overlying crust (Model A with Model B, Figure 8 and 9), Model A (experiments A1-A4) generally shows a high exhumation rate compared to Model B (experiments B1-B4). This indicates that the relay zone between faults in Model A prefers to concentrate the partially molten lower rocks compared to Model B (Figure 3). Experiments A5 and B5 having a ratio of 0.25 (extension rate to shear rate) do not show significant difference in the captured vertical velocity (Figures 8 and 9). In addition, the curves in Model A show a generally linear increase over time

30 prior to arriving about $10 \mathrm{~km}$ of uplift (Figure 8). For Model B, some early peaks of vertical velocity are observed at about 0.3Ma (Figure 9). 
Solid Earth Discuss., https://doi.org/10.5194/se-2017-142

Manuscript under review for journal Solid Earth

Discussion started: 30 January 2018

(c) Author(s) 2018. CC BY 4.0 License.

The difference in the paths of capturing vertical velocity between Model A and Model B probably suggests a different process of developing high strain zones and exhuming the partially molten lower crust exhumation took place in the relay zone between faults during extension and transtension. Since the pure extensional cases (experiments A1 and B1) do not show significant exhumation in the relay zone between faults (Figures 4A1 and 4B1), we thereby only focus on discussing the developmental process of the lower crust exhumation under transtension (experiments A2-A5 and B2-B5).

We here suggest a conceptual model (Figure 10) to explain the possible mechanisms that result in appearing early vertical velocity peaks in Figure 9. At a fault tip, it commonly has a maximum stress concentration (e.g., Cowie and Scholz, 1992; Vermilye and Scholz, 1999; Gupta and Scholz, 2000). The interaction between the tips of faults leads to the growth, 10 propagation and maturation of faults (Kim et al., 2001).

In Model A (Figure 10), nodes $\mathrm{n}$ and $\mathrm{p}$ (tips of faults) must intensely interact with a high stress concentration (e.g., Soliva et al., 2008) resulting in linking each other through fractures (Kim et al., 2001, 2004) when they are initially re-activated. After the re-activation, we can ideally mark the linked fractures as the blue line (Figure 10) according to the analogue (Peacock 15 and Parfitt, 2002; Bellahsen and Deniel, 2005), numerical modelling (Soliva et al., 2008) and field investigations (Acocella et al., 2000; Hus et al., 2006; Giba et al., 2012). The linked high strain zones are generally sub-orthogonal to the equivalent direction of transtension (red arrows in Figure 10). In other words, these high strain zones would be fully stretched over time by the equivalent transtensional boundary. This indicates that the partially molten lower crust rocks beneath the relay zone between faults would sub-linearly (as shown in Figure 8) exhume to the middle-upper crust along the blue line and its

20 surrounding areas (indicated by inclined black lines, Figure 10). This conclusion can be evidenced by both the spatial distribution (Figure 4) and the sub-linear exhumation rate (Figure 8) of the partially molten lower crust.

In terms of Model B, nodes $\mathrm{n}$ and $\mathrm{p}$ would undergo the same processes (concentrating high stress; e.g. Cowie and Scholz, 1992; Vermilye and Scholz, 1999; Gupta and Scholz, 2000) with Model A when they are initially re-activated. The strike of 25 the linked high strain zones (blue line in Model B, Figure 10) would be sub-parallel to the equivalent direction of transtension. This indicates that the linked high strain zones are not predominant sites (blue line of Model B) to concentrate strain over time in transtension. We propose that the linked high strain zones resulted from the initial re-activation (blue line in Model B, Figure 10) would be reprinted and overlapped during transtension (Kim et al., 2001). This probably can help explain the early peaks of vertical velocity observed in Model B (Figure 9). In addition, this conceptual model also indicates

30 that the newly produced high strain zones (indicated by inclined lines, Figure 10) would be generally sub-orthogonal to the equivalent direction of transtension. Partially molten lower crust rocks would exhume along the strike of the newly produced high strain zones. This feature coincides well with our numerical results (Figure 4), showing that the strike of the exhumation belt (red) made of the partially molten lower crust in the relay zone between faults is sub-orthogonal to the equivalent direction of transtension. 
Solid Earth Discuss., https://doi.org/10.5194/se-2017-142

Manuscript under review for journal Solid Earth

Discussion started: 30 January 2018

(c) Author(s) 2018. CC BY 4.0 License.

\subsection{Model implications for the Ghanaian Sefwi terrane}

Craton-scale shear zones in NW Ghana (Block et al., 2015; 2016) and SW (McFarlane et al., 2016) commonly mark the boundaries between low-grade greenstone belts and high-grade metamorphic rocks of up to amphibolite-migmatite facies. Identifying the role the shear zones play in the exhumation of the lower crust in Birimian province can allow to better understand the evolution of deformation during the Eburnean Orogeny (ca. 2.2-2.0Ga).

In the Sefwi terrane, the KJD high grade tectono-metamorphic domain is bounded by two main shear zones: the Ketesso and Kenyase shear zones. Based on the fault-induced exhumation of the lower crust shown by the numerical results (Figure 11a), the western boundary (red dotted line, Figure 11a) bounding the lower crustal materials is sub-parallel to the exhumation belt

10 (red belt) in the relay zone between faults, and is sub-orthogonal to the equivalent direction of transtension (red arrows in Figure 11a). This feature coincides well with the metamorphic map in the Sefwi terrane (McFarlane et al., 2017), the western boundary (purple dotted line in Figure 11b) of the KJD domain is sub-parallel to the distribution of migmatite (indicated by ellipse) and sub-orthogonal to the ENE-WSW transtension direction.

15 The concentration of the partially molten lower crust rocks increases along the direction from the relay zone to fault tips (Figure 11a). This can be used to explain the distribution of the migmatite-amphibolite bounded by an ellipse in the KJD domain, with a high concentration of migmatite around the heads of the ellipse (red and light blue areas, Figure 11b) and of amphibolite in the central part of the ellipse.

20 Regarding the evolution of structures, we suggest that the Ketesso and Kenyase shear zones probably underwent two stages for growth and maturation from the D1 to D2 deformation phases. During the D1 compression stage, the preliminary structures of the two shear zones were initialized in parallel. The Ketesso shear zones did not cross through the Sefwi terrane during the D1 stage, and they were located only in the southern part of the Sefwi terrane (dark blue dotted line, Figure 11b). At the same time, the preliminary forms of the Kenyase shear zones were located only in the northern part of the Sefwi terrane (dark blue dotted line, Figure 11b). This distribution of the two shear zones probably resulted from a significantly oblique component of the D1 compression stage. These preliminary structures of the Ketesso and Kenyase shear zones provided preferential sites for subsequent re-activation. During the subsequent D2 transtension, the two shear zones developed along their initial strikes (pink dotted lines) and became matured.

30 With respect to the high-grade rocks observed in the North-Eastern part of the Sefwi terrane (indicated by black dotted box, Figure 11b), if we accept this model, this could be explained by regional exhumation controlled and promoted by the newly matured part (pink dotted part, Figure 11b) of the Ketesso shear zones during the D2 transtension. Second-order faults 
Solid Earth Discuss., https://doi.org/10.5194/se-2017-142

Manuscript under review for journal Solid Earth

Discussion started: 30 January 2018

(c) Author(s) 2018. CC BY 4.0 License.

between the two main shear zones (the Ketesso and Kenyase shear zones) could also have made a significant contribution to the exhumation of the high-grade rocks.

Regarding the time length required for the regional exhumation of the partially molten lower crust (about $10 \mathrm{~km}$ of uplift equalling to a drop in pressure of 4kbar during the D2 transtension stage suggested by McFarlane et al., 2016), according to our numerical experiments, all the modelling results yield a similar time length of less than 2Ma when using rates of 1$2 \mathrm{~cm} /$ year for extension and $0-4 \mathrm{~cm} /$ year for shear. Considering the variations in velocities (Vs and Ve) applied on boundaries, we suggest that the main regional exhumation of the lower crust in the Sefwi terrane probably occurred within a short duration of less than $5 \mathrm{Ma}$.

\section{$10 \quad 5.4$ Limitations and perspectives}

Although we have tested ten 3D thermo-mechanical models under extension and transtension boundary conditions, the ratio of extension rate to shear rate applied on boundaries should be more extensively tested in further models. In our study, we focused our attentions on exploring the regional re-distribution of the lower crust exhumation influenced by the spatial relationship of pre-existing faults and boundary conditions, and the process of fluid transfer in fractures/faults was thus

15 deliberately not included, but we aim to couple this process in future studies by employing solid-fluid mechanisms developed by Keller et al. (2013). Regarding the effective viscosity of partially molten rocks, it's still overestimated in this study compared to the experimental results (between $10^{6}-10^{18} \mathrm{~Pa} \mathrm{~s}$; Vanderhaeghe, 2001). This is due to the high consumption in computing huge viscosity variations (Moresi and Solomatov, 1995).

20 We aim to improve the setup of the initial model (e.g., more realistic spatial-relationship of pre-existing faults, dating the timing of main structures in the study area) under the assistance of more field works in the future. In addition, we only concerned here the D2 deformation stage occurred in the Sefwi terrane of SW Ghana. We installed the initial model according to the geological data estimated at the end of the D1 deformation stage (P, T and crustal thickness based on the metamorphic estimates performed by Block et al. (2015) and McFarlane et al. (2016)). In particular, the variation in the

25 distribution of the Moho depth (Jessell et al., 2016) resulting from the D1 compression stage was not taken into considerations for modelling. That could be interesting if we can perform a continuous process for the Sefwi terrane by including the D1 crustal thickening (Feng et al., 2016a) and the D2 transtension triggering the regional exhumation. In addition, we aim to involve more geophysical and geochemical constrains (Ganne et al., 2016) to improve the model setup (e.g., geochronological data; more P-T paths; distribution of Moho depth; thickness of the lithosphere and the mantle 30 potential temperature during the Eburnean Orogeny etc.). 
Solid Earth Discuss., https://doi.org/10.5194/se-2017-142

Manuscript under review for journal Solid Earth

Discussion started: 30 January 2018

(c) Author(s) 2018. CC BY 4.0 License.

\section{Conclusions}

In this study, we constructed ten 3D thermo-mechanical model to test the role pre-existing faults and boundary conditions play in the re-distribution of the exhumation of the lower crust. Different patterns of faults and boundary conditions were tested.

The 3D models show that the normal component of boundary conditions in the fault system controls the exhumation of the lower crust along faults, while the exhumation in the relay zone between faults is dominated by the ratio of extension rate to shear rate applied on boundaries. The strike of the exhumation belt made of partially molten lower crustal materials in the relay zone between faults is sub-orthogonal to the transtension direction. The spatial relationship of faults controls the 10 distribution of surface relief in general. The maximum subsidence and uplift yield relief values of about $-2 \mathrm{~km}$ and $2 \mathrm{~km}$, respectively. The isostatic compensation from the low-density upper mantle to the overlying crust (crustal thinning) is higher under transtension than that under extension.

The re-distribution of the partially molten lower crust rocks controlled by high strain zones can be used to better understand

15 the loci of the high-grade rocks in the Sefwi terrane. The Kukuom-Juaboso domain (KJD) comprised of up to amphibolitemigmatite facies probably resulted from the concentration of the partially molten rocks in the relay zone between the Ketesso and Kenyase shear zones during the D2 ENE-WSW transtension (a drop in pressure of about 4kbar). These two shear zones could undergo two phases for development and growth from the D1 to D2 deformation stages. The mainly regional exhumation in the Sefwi terrane probably occurred within a duration of less than 5Ma.

\section{Acknowledgements}

This project is supported by "the Fundamental Research Funds for the Central Universities" and funded by the Priority Academic Program Development of Jiangsu Higher Education Institutions (PAPD). Helen McFarlane is greatly thanked for fruitful discussions on this paper and providing us the metamorphic maps of SW Ghana. We also thank the development team at the Victorian Partnership for Advanced Computing (VPAC) and Monash University for patient assistance with the numerical code Underworld over years. Figures are plotted using open source package Visit developed by the Lawrence Livermore National Laboratory, they are thanked for providing some helpful suggestions on producing figures.

\section{References}

Abers, G. A., Ferris, A., Craig, M., Davies, H., Lerner-Lam, A. L., Mutter, J. C., Taylor, B., 2002. Mantle compensation of active metamorphic core complexes at Woodlark rift in Papua New Guinea. Nature, 418, 862-865.

30 Acocella, V., Gudmundsson, A., Funiciello, R., 2000. Interaction and linkage of extension fractures and normal faults: examples from the rift zone of Iceland. Journal of Structural Geology, 22, 1233-1246. 
Solid Earth Discuss., https://doi.org/10.5194/se-2017-142

Manuscript under review for journal Solid Earth

Discussion started: 30 January 2018

(c) Author(s) 2018. CC BY 4.0 License.

Agyei Duodu, J., Loh, G.K., Boamah, K.O., 2009. Geological map of Ghana 1:1 000 000. Geological Survey Department of Ghana (GSD).

Baratoux, L., Metelka, V., Naba, S., Jessell, M. W., Grégoire, M., Ganne, J., 2011. Juvenile Paleoproterozoic crust evolution during the Eburnean orogeny ( 2.2-2.0Ga), western Burkina Faso. Precambrian Research, 191, 18-45.

Banks, R. J., Parker, R. L., Huestis, S. P., 1977. Isostatic compensation on a continental scale: local versus regional mechanisms. Geophysical Journal International, 51, 431-452.

Banks, R.J. Swain, C.J., 1978. The isostatic compensation of East Africa. In Proceedings of the Royal Society of London: Mathematical, Physical and Engineering Sciences (Vol. 364, No. 1718, pp. 331-352). The Royal Society.

Beekman, F., Bull, J. M., Cloetingh, S. A. P. L., Scrutton, R. A., 1996. Crustal fault reactivation facilitating lithospheric folding/buckling in the central Indian Ocean. Geological Society, London, Special Publications, 99, $251-263$.

Bellahsen, N., Daniel, J. M., 2005. Fault reactivation control on normal fault growth: an experimental study. Journal of Structural Geology, 27, 769-780.

Block, S., Ganne, J., Baratoux, L., Zeh, A., Parra-Avila, L. A., Jessell, M., Ailleres, L., Siebenaller, L., 2015. Petrological and geochronological constraints on lower crust exhumation during Paleoproterozoic (Eburnean) orogeny, NW Ghana, West African Craton. Journal of Metamorphic Geology, 33, 463-494.

Block, S., Jessell, M., Aillères, L., Baratoux, L., Bruguier, O., Zeh, A., Bosch, D., Caby, R. and Mensah, E., 2016. Lower crust exhumation during Paleoproterozoic (Eburnean) orogeny, NW Ghana, West African Craton: interplay of coeval contractional deformation and extensional gravitational collapse. Precambrian Research, 274, 82-109.

Brun, J. P., Sokoutis, D., Van Den Driessche, J., 1994. Analogue modeling of detachment fault systems and core complexes. Geology, 22, 319-322.

Burov, E., Jolivet, L., Le Pourhiet, L., Poliakov, A., 2001. A thermomechanical model of exhumation of high pressure (HP) and ultra-high pressure (UHP) metamorphic rocks in Alpine-type collision belts. Tectonophysics, 342, 113-136.

Chester, J. S., Logan, J. M., Spang, J. H., 1991. Influence of layering and boundary conditions on fault-bend and faultpropagation folding. Geological Society of America Bulletin, 103, 1059-1072.

Cowie, P. A., Scholz, C. H., 1992. Physical explanation for the displacement-length relationship of faults using a post-yield fracture mechanics model. Journal of Structural Geology, 14(10), 1133-1148.

D'Agostino, N., Chamot-Rooke, N., Funiciello, R., Jolivet, L., Speranza, F., 1998. The role of pre-existing thrust faults and topography on the styles of extension in the Gran Sasso range (central Italy). Tectonophysics, 292, $229-254$.

Dewey, J. F., Holdsworth, R. E., Strachan, R. A., 1998. Transpression and transtension zones. Geological Society, London, Special Publication, 135, 1-14.

Drucker, D. C., Prager, W., 2013. Soil mechanics and plastic analysis or limit design. Quarterly of applied mathematics, 10.

Dooley, T. P., Schreurs, G., 2012. Analogue modelling of intraplate strike-slip tectonics: A review and new experimental results. Tectonophysics, 574, 1-71.

Egal, E., Thiéblemont, D., Lahondere, D., Guerrot, C., Costea, C.A., Iliescu, D., Delor, C., Goujou, J.C., Lafon, J.M., Tegyey, M. and Diaby, S., 2002. Late Eburnean granitization and tectonics along the western and northwestern margin of the Archaean Kénéma-Man domain (Guinea, West African Craton). Precambrian Research, 117, 57-84.

Faulkner, D. R., Jackson, C. A. L., Lunn, R. J., Schlische, R. W., Shipton, Z. K., Wibberley, C. A. J., Withjack, M. O., 2010. A review of recent developments concerning the structure, mechanics and fluid flow properties of fault zones. Journal of Structural Geology, 32, 1557-1575. 
Solid Earth Discuss., https://doi.org/10.5194/se-2017-142

Manuscript under review for journal Solid Earth

Discussion started: 30 January 2018

(C) Author(s) 2018. CC BY 4.0 License.

Feng, X., Amponsah, P. O., Martin, R., Ganne, J., Jessell, M. W., 2016a. 3-D numerical modelling of the influence of preexisting faults and boundary conditions on the distribution of deformation: example of North-Western Ghana. Precambrian Research, 274, 161-179.

Feng, X., Jessell, M. W., Amponsah, P. O., Martin, R., Ganne, J., Liu, D., Batt, E. G., 2016b. Effect of strain-weakening on Oligocene-Miocene self-organization of the Australian-Pacific plate boundary fault in southern New Zealand: Insights from numerical modelling. Journal of Geodynamics, doi: 10.1016/j.jog.2016.03.002.

Feng, X., Enyuan Wang., Amponsah, P. O., Ganne, J., Martin, R., Jessell, M. W., 2018. Influence of pre-existing faults on the distribution of lower crust exhumation under extension: Numerical modelling and Implications for NW Ghana, Journal of Structural geology. (Under review)

10 Feybesse, J. L., Billa, M., Guerrot, C., Duguey, E., Lescuyer, J. L., Milesi, J. P., Bouchot, V., 2006. The paleoproterozoic Ghanaian province: geodynamic model and ore controls, including regional stress modeling. Precambrian Research, 149, 149-196.

Fossen, H., Tikoff, B., 1998. Extended models of transpression and transtension, and application to tectonic settings. Geological Society, London, Special Publications, 135, 15-33.

15 Ganne, J., De Andrade, V., Weinberg, R.F., Vidal, O., Dubacq, B., Kagambega, N., Naba, S., Baratoux, L., Jessell, M., Allibon, J., 2012. Modern-style plate subduction preserved in the Palaeoproterozoic West African craton. Nature Geoscience, 5, 60-65.

Ganne, J., Gerbault, M., Block, S., 2014. Thermo-mechanical modeling of lower crust exhumation-Constraints from the metamorphic record of the Palaeoproterozoic Eburnean orogeny, West African Craton. Precambrian Research, 243, 88-109.

Ganne, J., Feng, X., Rey, P., Andrade, V. D., 2016. Statistical Petrology Reveals a Link Between Supercontinents Cycle and Mantle Global Climate. American Mineralogist. Doi. org/10.2138/am-2016-5868.

Gerya, T. V., Yuen, D. A., 2003. Rayleigh-Taylor instabilities from hydration and melting propel 'cold plumes' at subduction zones. Earth and Planetary Science Letters, 212, 47-62.

25 Gerya, T. V., Burg, J. P., 2007. Intrusion of ultramafic magmatic bodies into the continental crust: numerical simulation. Physics of the Earth and Planetary Interiors, 160, 124-142.

Gerya, T. V., Perchuk, L. L., Burg, J. P., 2008. Transient hot channels: perpetrating and regurgitating ultrahigh-pressure, high-temperature crust-mantle associations in collision belts. Lithos, 103, 236-256.

Giba, M., Walsh, J. J., Nicol, A., 2012. Segmentation and growth of an obliquely reactivated normal fault. Journal of Structural Geology, 39, 253-267.

Gueydan, F., Précigout, J., Montesi, L. G., 2014. Strain weakening enables continental plate tectonics. Tectonophysics, 631, 189-196.

Gupta, A., Scholz, C. H., 2000. A model of normal fault interaction based on observations and theory. Journal of Structural Geology, 22, 865-879.

Rollinson, H., 2016. Archaean Crustal evolution in West Africa: A new synthesis of the Archaean geology in Sierra Leone, Liberia, Guinea and Ivory Coast, Precambrian Research, doi: http://dx.doi.org/ 10.1016/j.precamres.2016.05.005

Hirdes, W., Davis, D.W., Eisenlohr, B.N., 1992. Reassessment of Proterozoic granitoid ages in Ghana on the basis of U/Pb zircon and monazite dating. Precambrian Research, 56, 89-96.

Hirdes, W., Davis, D.W., Lüdtke, G., Konan, G., 1996. Two generations of Birimian (Paleoproterozoic) volcanic belts in northeastern Côte d'Ivoire (West Africa): consequences for the "Birimian controversy." Precambrian Research, 80, 173-191. 
Solid Earth Discuss., https://doi.org/10.5194/se-2017-142

Manuscript under review for journal Solid Earth

Discussion started: 30 January 2018

(c) Author(s) 2018. CC BY 4.0 License.

Huet, B., Le Pourhiet, L., Labrousse, L., Burov, E., Jolivet, L., 2011. Post-orogenic extension and metamorphic core complexes in a heterogeneous crust: the role of crustal layering inherited from collision. Application to the Cyclades (Aegean domain). Geophysical Journal International, 184, 611-625.

Hus, R., De Batist, M., Klerkx, J., Matton, C., 2006. Fault linkage in continental rifts: structure and evolution of a large relay ramp in Zavarotny; Lake Baikal (Russia). Journal of structural geology, 28, 1338-1351.

Jessell, M. W., Siebert, E., Bons, P. D., Evans, L., Piazolo, S., 2005. A new type of numeri-cal experiment on the spatial and temporal patterns of localization of defor-mation in a material with a coupling of grain size and rheology. Earth and Planetary Science Letters, 239, 309-326.

Jessell, M. W., Bons, P. D., Griera, A., Evans, L. A., Wilson, C. J., 2009. A tale of two vis-cosities. Journal of Structural Geology, 31, 719-736.

Jessell, M. W., Amponsah, P. O., Baratoux, L., Asiedu, D. K., Loh, G. K., Ganne, J., 2012. Crustal-scale transcurrent shearing in the Paleoproterozoic Sefwi-Sunyani-Comoé region, West Africa. Precambrian Research, 212-213, 155168.

Jessell, M. W., Begg, G. C., Miller, M. S., 2016. The geophysical signatures of the West African Craton. Precambrian Research, 274, 3-24.

Keller, T., May, D. A., Kaus, B. J., 2013. Numerical modelling of magma dynamics coupled to tectonic deformation of lithosphere and crust. Geophysical Journal International, 195, 1406-1442.

Kim, Y. S., Andrews, J. R., Sanderson, D. J., 2001. Reactivated strike-slip faults: examples from north Cornwall, UK. Tectonophysics, 340, 173-194.

20 Kim, Y. S., Peacock, D. C., Sanderson, D. J., 2004. Fault damage zones. Journal of structural geology, 26, 503-517.

Kim, Y. S., Sanderson, D. J., 2005. The relationship between displacement and length of faults: a review. Earth-Science Reviews, 68, 317-334.

Koyi, H. A., Skelton, A., 2001. Centrifuge modelling of the evolution of low-angle detachment faults from high-angle normal faults. Journal of structural Geology, 23, 1179-1185.

25 Le Pourhiet, L., Burov, E., Moretti, I., 2004. Rifting through a stack of inhomogeneous thrusts (the dipping pie concept). Tectonics, 23(4).

Le Pourhiet, L., Huet, B., May, D. A., Labrousse, L., Jolivet, L., 2012. Kinematic interpretation of the 3D shapes of metamorphic core complexes. Geochemistry, Geophysics, Geosystems, 13(9).

Liao, J., Gerya, T., 2014. Influence of lithospheric mantle stratification on craton extension: Insight from two-dimensional thermo-mechanical modeling. Tectonophysics, 631, 50-64.

Lin, C. H., 2000. Thermal modeling of continental subduction and exhumation constrained by heat flow and seismicity in Taiwan. Tectonophysics, 324, 189-201.

Lin, S., Jiang, D., Williams, P. F., 1998. Transpression (or transtension) zones of triclinic symmetry: natural example and theoretical modelling. Geological Society, London, Special Publications, 135, 41-57.

Luyendyk, B. P., 1991. A model for Neogene crustal rotations, transtension, and transpression in southern California. Geological Society of America Bulletin, 103, 1528-1536.

McFarlane, H. B., Block, S., Ailleres, L., Betts, P., Ganne, J., Baratoux, L., Jessell, M., 2016. Lower and middle crust exhumation during Palaeoproterozoic accretionary tectonics: Key new evidence from the Sefwi Greenstone Belt, SW Ghana. $35^{\text {th }}$ International Geological Congress (IGC), 27 AUGUST-4 SEPTEMBER 2016, Cape Town, South Africa, abstract. 
Solid Earth Discuss., https://doi.org/10.5194/se-2017-142

Manuscript under review for journal Solid Earth

Discussion started: 30 January 2018

(c) Author(s) 2018. CC BY 4.0 License.

McFarlane, H. B., Block, S., Ganne, J., Baratoux, L., Ailleres, L., Betts, P., Jessell, M., Armstrong, R. 2017. Petrological and geochronological evidence of collisional orogenesis and lower crust exhumation during the Palaeoproterozoic Eburnean Orogeny, SW Ghana, West African Cratoon. Journal of Metamorphic geology (accept with revision).

Milési, J.P., Feybesse, J.L. Pinna, P. et al., 2004. Geological map of Africa 1:10,000,000, SIGAfrique project. In: 20th Conference of African Geology. BRGM, Orleans, France, 2-7 June. Available at: http://www.sigafrique.net.

Moresi, L., Solomatov, S., 1995. Numerical investigation of 2D convection with extremely large viscosity variations. Physics of Fluids (1994-present) 7, 2154-2162.

Moresi, L., Dufour, F., Mühlhaus, H. B., 2003. A Lagrangian integration point finite element method for large deformation modeling of viscoelastic geomaterials. Journal of Computational Physics, 184, 476-497.

10 Moresi, L., Quenette, S., Lemiale, V., Meriaux, C., Appelbe, B., Muhlhaus, H., 2007. Computational approaches to studying non-linear dynamics of the crust and mantle. Physics of the Earth and Planetary Interior, 163, 69-82.

Morley, C. K., 1999. How successful are analogue models in addressing the influence of pre-existing fabrics on rift structure? Journal of Structural Geology, 21, 1267-1274.

Morley, C. K., Haranya, C., Phoosongsee, W., Pongwapee, S., Kornsawan, A., Wonganan, N., 2004. Activation of rift oblique and rift parallel pre-existing fabrics during extension and their effect on deformation style: examples from the rifts of Thailand. Journal of Structural Geology, 26, 1803-1829.

Neves, S. P., Vauchez, A., Feraud, G., 2000. Tectono-thermal evolution, magma emplacement, and shear zone development in the Caruaru area (Borborema Province, NE Brazil). Precambrian Research, 99, 1-32.

Pachell, M. A., Evans, J. P., 2002. Growth, linkage, and termination processes of a 10-km-long strike-slip fault in jointed granite: the Gemini fault zone, Sierra Nevada, California. Journal of structural geology, 24, 1903-1924.

Peacock, D. C. P., Parfitt, E. A., 2002. Active relay ramps and normal fault propagation on Kilauea Volcano, Hawaii. Journal of structural geology, 24, 729-742.

Piccardo, G. B., 2016. Evolution of the lithospheric mantle during passive rifting: Inferences from the Alpine-Apennine orogenic peridotites. Gondwana Research.

25 Ranalli, G., 1995. Rheology of the Earth. Springer Science \& Business Media. pp. 413.

Rey, P.F., Teyssier, C., Whitney, D.L., 2009a. Extension rates, crustal melting, and core complex dynamics. Geology, 37, 391-394.

Rey, P.F., Teyssier, C., Whitney, D.L., 2009b. The role of partial melting and extensional strain rates in the development of metamorphic core complexes. Tectonophysics, 477, 135-144.

30 Rey, P.F., Teyssier, C., Kruckenberg, S.C., Whitney, D.L., 2011. Viscous collision in channel explains double domes in metamorphic core complexes. Geology, 39, 387-390.

Sakyi, P. A., Su, B. X., Anum, S., Kwayisi, D., Dampare, S. B., Anani, C. Y., Nude, P. M., 2014. New zircon U-Pb ages for erratic emplacement of 2213-2130Ma Paleoproterozoic calc-alkaline I-type granitoid rocks in the Lawra Volcanic Belt of Northwestern Ghana, West Africa. Precambrian Research, 254, 149-168.

35 Seyferth, M., Henk, A., 2004. Syn-convergent exhumation and lateral extrusion in continental collision zones-Insights from three-dimensional numerical models. Tectonophysics, 382, 1-29.

Sharples, W., Moresi, L. N., Jadamec, M. A., Revote, J., 2015. Styles of rifting and fault spacing in numerical models of crustal extension. Journal of Geophysical Research: Solid Earth, 120, 4379-4404.

Soliva, R., Benedicto, A., Schultz, R. A., Maerten, L., Micarelli, L., 2008. Displacement and interaction of normal fault segments branched at depth: Implications for fault growth and potential earthquake rupture size. Journal of Structural Geology, 30, 1288-1299. 
Solid Earth Discuss., https://doi.org/10.5194/se-2017-142

Manuscript under review for journal Solid Earth

Discussion started: 30 January 2018

(c) Author(s) 2018. CC BY 4.0 License.

(c) (1)

Teufel, L. W., Clark, J. A., 1984. Hydraulic fracture propagation in layered rock: experimental studies of fracture containment. Society of Petroleum Engineers Journal, 24, 19-32.

Tirel, C., Brun, J. P., Burov, E., 2008. Dynamics and structural development of metamorphic core complexes. Journal of Geophysical Research: Solid Earth, 113(B4).

5 Vanderhaeghe, O., 2001. Melt segragation, pervasive melt migration and magma mobility in the continental crust: the structural record from pores to orogens. Physics and Chemistry of the Earth, Part A: Solid Earth and Geodesy, 26, 213-223.

Vermilye, J. M., Scholz, C. H., 1999. Fault propagation and segmentation: insight from the microstructural examination of a small fault. Journal of Structural Geology, 21, 1623-1636.

10 Weinberg, R. F., Mark, G., Reichardt, H., 2006. Magma ponding in the Karakoram shear zone, Ladakh, NW India. Geological Society of America Bulletin, 121, 278-285. 
Solid Earth Discuss., https://doi.org/10.5194/se-2017-142

Manuscript under review for journal Solid Earth

Discussion started: 30 January 2018

(C) Author(s) 2018. CC BY 4.0 License.

Table 1: Experiments with different parameters on boundary conditions.

\begin{tabular}{|c|c|c|c|c|c|c|}
\hline Pattern & Exp\# & $\begin{array}{l}\text { Extension rate } \\
(V e, \mathrm{~cm} / \text { year })\end{array}$ & $\begin{array}{c}\text { Shear rate } \\
(V s, \mathrm{~cm} / \text { year })\end{array}$ & $V e / V s$ & $\begin{array}{c}\text { Von Mises } \\
\text { strain* }\left(\varepsilon_{e q}\right)\end{array}$ & $\begin{array}{l}\text { Normalized } \\
\text { /year }\left(10^{-6}\right)\end{array}$ \\
\hline \multirow{5}{*}{ Model A } & $\mathrm{A} 1$ & 2 & 0 & $\infty$ & 0.09 & 0.10 \\
\hline & $\mathrm{A} 2$ & 2 & 1 & 2 & 0.10 & 0.13 \\
\hline & A3 & 2 & 2 & 1 & 0.16 & 0.19 \\
\hline & A4 & 1 & 2 & 0.5 & 0.28 & 0.17 \\
\hline & A5 & 1 & 4 & 0.25 & 0.51 & 0.33 \\
\hline \multirow{5}{*}{ Model B } & B1 & 2 & 0 & $\infty$ & 0.08 & 0.10 \\
\hline & B2 & 2 & 1 & 2 & 0.11 & 0.13 \\
\hline & B3 & 2 & 2 & 1 & 0.16 & 0.19 \\
\hline & B4 & 1 & 2 & 0.5 & 0.29 & 0.17 \\
\hline & B5 & 1 & 4 & 0.25 & 0.41 & 0.33 \\
\hline
\end{tabular}

* The Von Mises equivalent strain is calculated by: $\varepsilon_{e q}=\frac{2}{3} \sqrt{\frac{3\left(e_{x x}^{2}+e_{y y}^{2}+e_{z z}^{2}\right)}{2}+\frac{3\left(\gamma_{x y}^{2}+\gamma_{y z}^{2}+\gamma_{z x}^{2}\right)}{4}}$. 
Solid Earth Discuss., https://doi.org/10.5194/se-2017-142

Manuscript under review for journal Solid Earth

Discussion started: 30 January 2018

(C) Author(s) 2018. CC BY 4.0 License.

(c) (1)

Table 2. Thermo-mechanical model parameters, symbol and value-units.

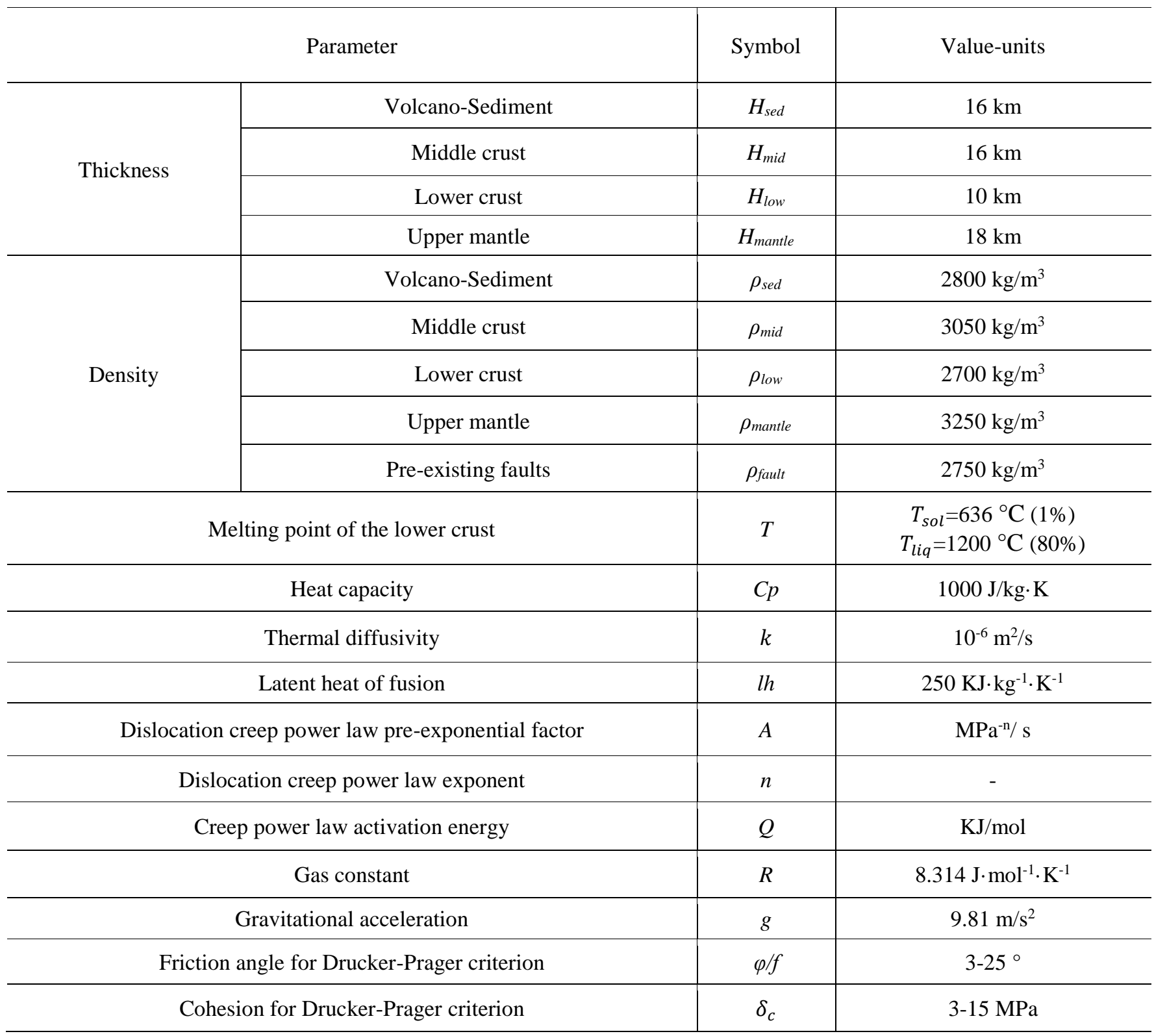


Solid Earth Discuss., https://doi.org/10.5194/se-2017-142

Manuscript under review for journal Solid Earth

Discussion started: 30 January 2018

(c) Author(s) 2018. CC BY 4.0 License.

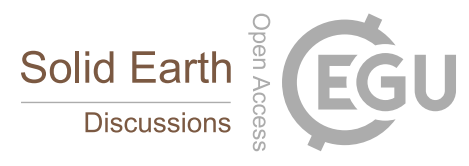

(c) (1)

Table 3. Rheological parameters employed for modelling different lithospheric layers are collected from Ranalli, (1995). The effective viscosity is calculated with a non-Newtonian power law using the equation: $\eta_{0}=0.25 \cdot(0.75 A)^{(-1 / n)} \cdot \dot{\varepsilon}^{((1 / n)-1)}$. $\exp ^{(Q / n R T)}$.

\begin{tabular}{cllll}
\hline Layer & Rock type & $\mathrm{A}\left(\mathrm{MPa}^{-\mathrm{n}} / \mathrm{s}\right)$ & $\mathrm{n}$ & $\mathrm{Q}(\mathrm{KJ} / \mathrm{mol})$ \\
\hline Volcano-Sediment & Wet quartzite & $3.2 \times 10^{-4}$ & 2.3 & 154 \\
Middle crust & Diabase & $2.0 \times 10^{-4}$ & 3.4 & 260 \\
Lower crust & Quartzodiorite & $1.3 \times 10^{-3}$ & 2.4 & 219 \\
Upper mantle & Dry olivine & $7 \times 10^{4}$ & 3.3 & 520 \\
\hline Pre-existing fault & & \multicolumn{3}{c}{ Initial viscosity $\left(10^{20} \mathrm{~Pa} \mathrm{~s}\right)$} \\
\hline
\end{tabular}


Solid Earth Discuss., https://doi.org/10.5194/se-2017-142

Manuscript under review for journal Solid Earth

Discussion started: 30 January 2018

(c) Author(s) 2018. CC BY 4.0 License.

(c) (i)

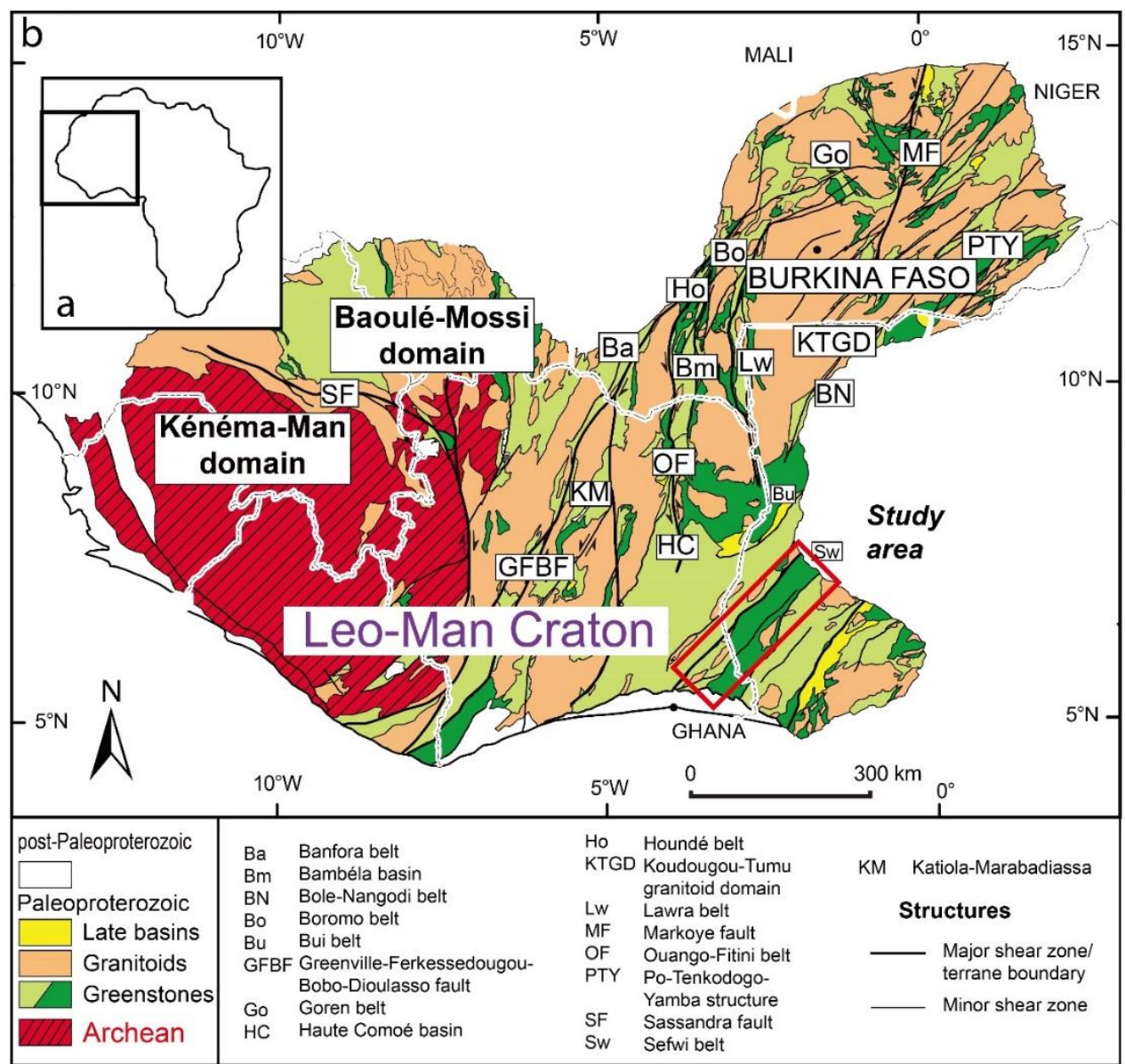

Figure 1. Geological map of the Leo-Man Craton of the WAC after Milési et al. (2004). It shows major shear zones and

Paleoproterozoic-Archaean blocks. The Ghanaian Sefwi domain is indicated by a red box, a detailed metamorphic and structural map can be found in Figure 2. 
Solid Earth Discuss., https://doi.org/10.5194/se-2017-142

Manuscript under review for journal Solid Earth

Discussion started: 30 January 2018

(c) Author(s) 2018. CC BY 4.0 License.

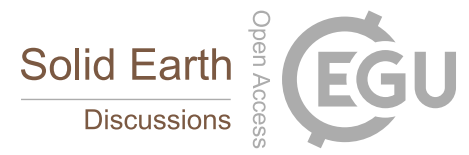

(c) (i)

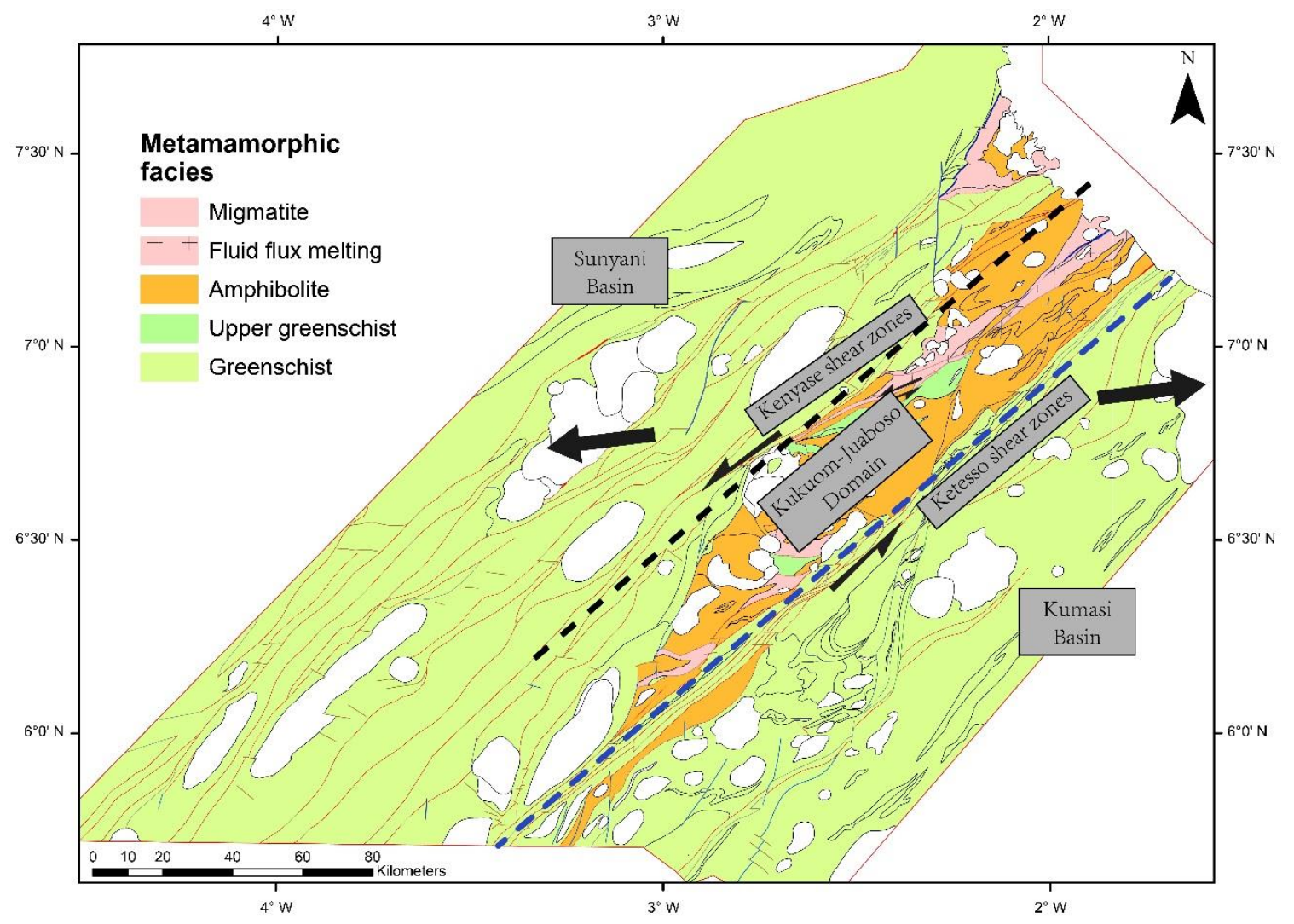

Figure 2. Metamorphic map of the Sefwi terrane of SW Ghana after McFarlane et al. (2017). The D2 deformation stage was dominated by the D2 ENE-WSW transtension (indicated by black arrows). The KJD high grade domain is bounded by two shear zones: the Kenyase shear zones and the Ketesso shear zones (indicated by black and blue dotted lines). 
Solid Earth Discuss., https://doi.org/10.5194/se-2017-142

Manuscript under review for journal Solid Earth

Discussion started: 30 January 2018

(c) Author(s) 2018. CC BY 4.0 License.

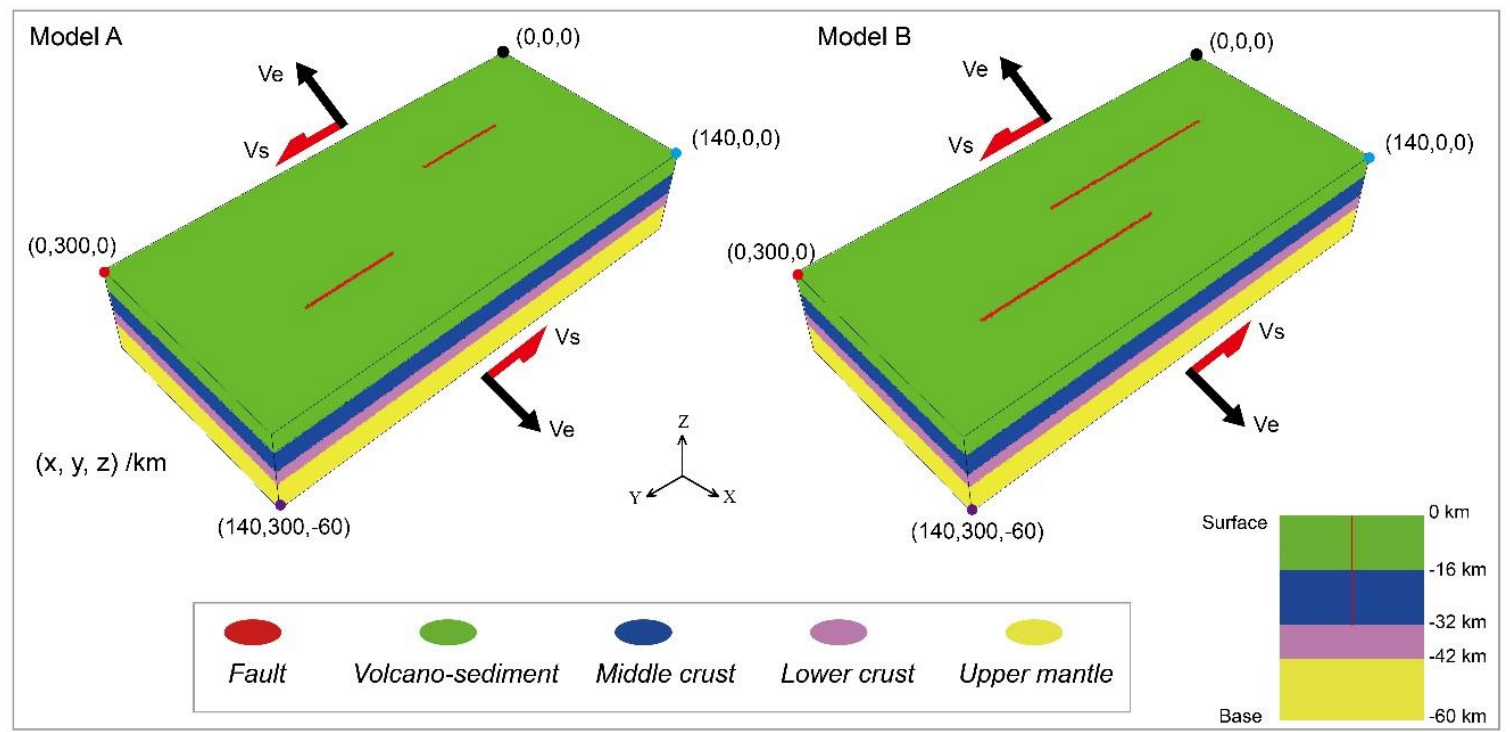

Figure 3. 3D numerical models are built with the numerical code Underworld (Moresi et al., 2003, 2007). The mechanical boundary conditions are indicated by black and red arrows. Two interacting vertical faults with a thickness of $2 \mathrm{~km}$ (Le Pourhiet et al., 2004) are initialized in Model A and Model B (red colour). The difference between Model A and Model B is in the spatial

5 relationship between faults (with or without an overlapping zone between two parallel faults). 450 passive particles divided into two groups are placed in the upper surfaces of the lower crust $(Z=-32 \mathrm{~km})$ and the upper mantle $(Z=-42 \mathrm{~km})$, respectively. 
Solid Earth Discuss., https://doi.org/10.5194/se-2017-142

Manuscript under review for journal Solid Earth

Discussion started: 30 January 2018

(c) Author(s) 2018. CC BY 4.0 License.

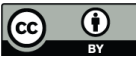

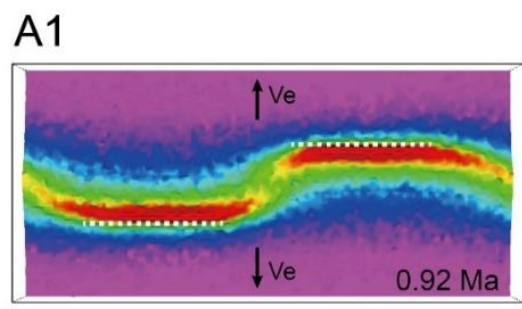

\section{A2}

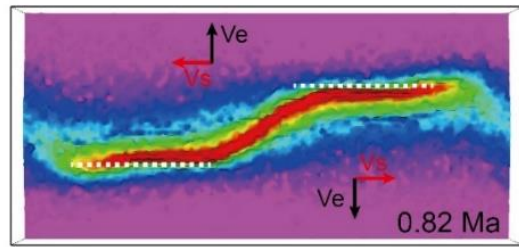

A3

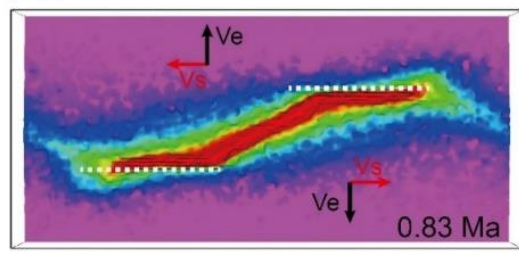

A4

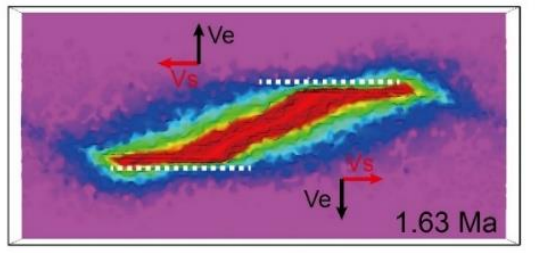

A5

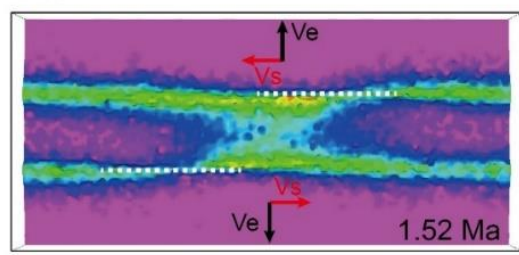

0
B1

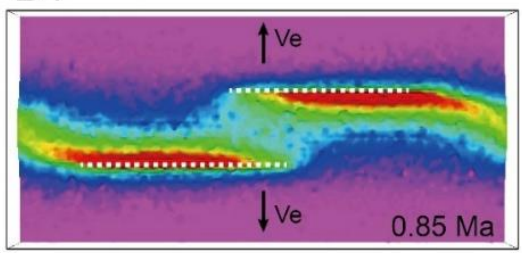

B2

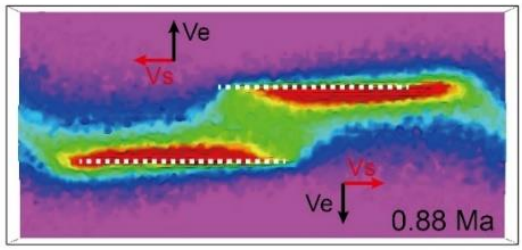

B3

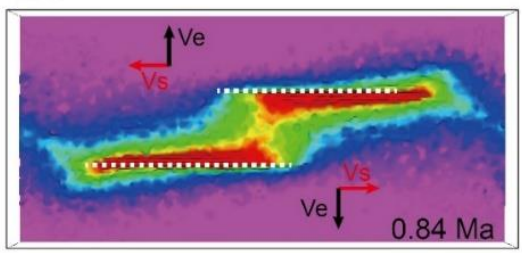

B4

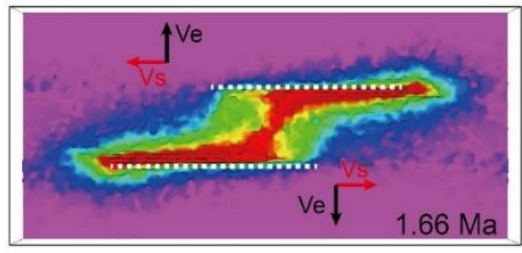

B5

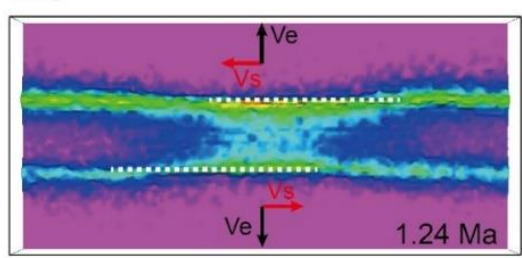

5

$\geq 10 \mathrm{~km}$

Figure 4. The relief of the upper surface of the partially molten lower crust in extension (experiments A1 and B1) and transtension (experiments A2-A5 and B2-B5). The first and second columns correspond to the different standard models: Model A and Model B (Figure 3), respectively. Pre-existing faults are indicated in white dotted lines. Boundary conditions are indicated by black and 5 red arrows. The colour bar represents the exhumation of the partially molten lower crust during extension and transtension. 
Solid Earth Discuss., https://doi.org/10.5194/se-2017-142

Manuscript under review for journal Solid Earth

Discussion started: 30 January 2018

(c) Author(s) 2018. CC BY 4.0 License.

(c) (i)

A1

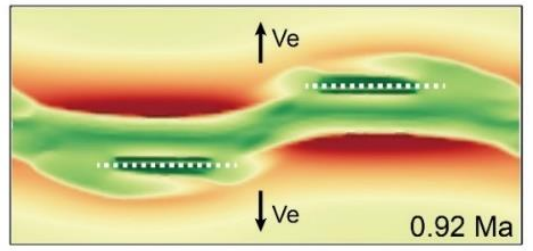

A2

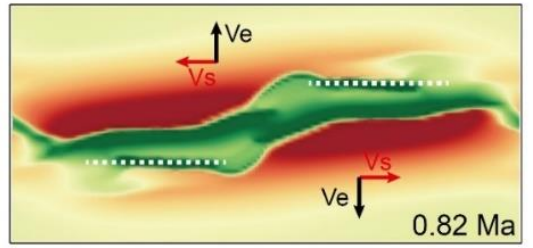

A3

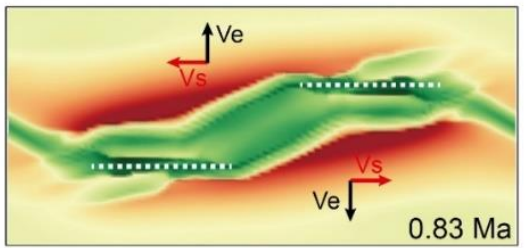

A4

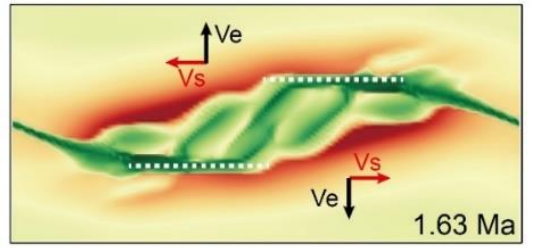

A5

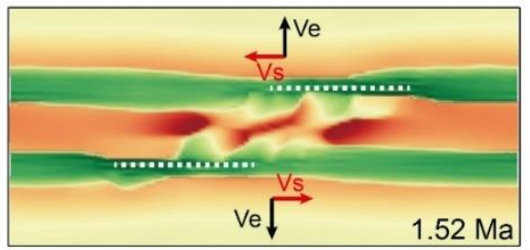

$-2 \mathrm{~km}$
B1

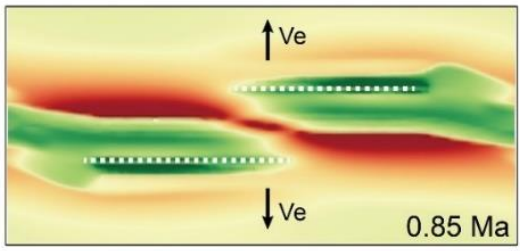

B2

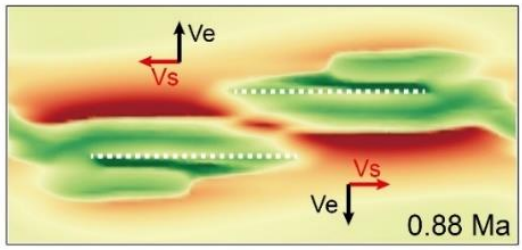

B3

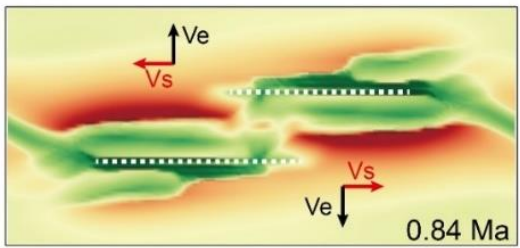

B4

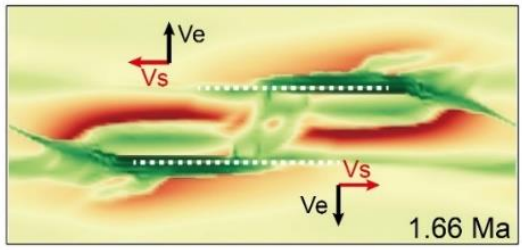

B5

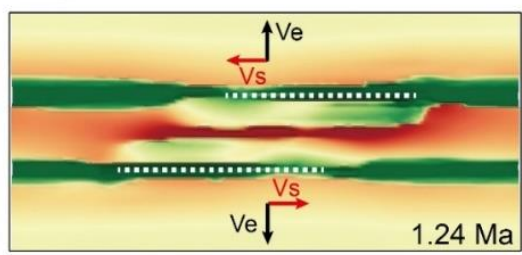

0

$2 \mathrm{~km}$

Figure 5. The surface relief influenced by different ratios of extension rate to shear rate applied and the spatial relationship of faults. The first and second columns correspond to the standard models: Model A and Model B (Figure 3), respectively. Preexisting faults are indicated in white dotted lines. Boundary conditions are indicated by black and red arrows. 
Solid Earth Discuss., https://doi.org/10.5194/se-2017-142

Manuscript under review for journal Solid Earth

Discussion started: 30 January 2018

(c) Author(s) 2018. CC BY 4.0 License.
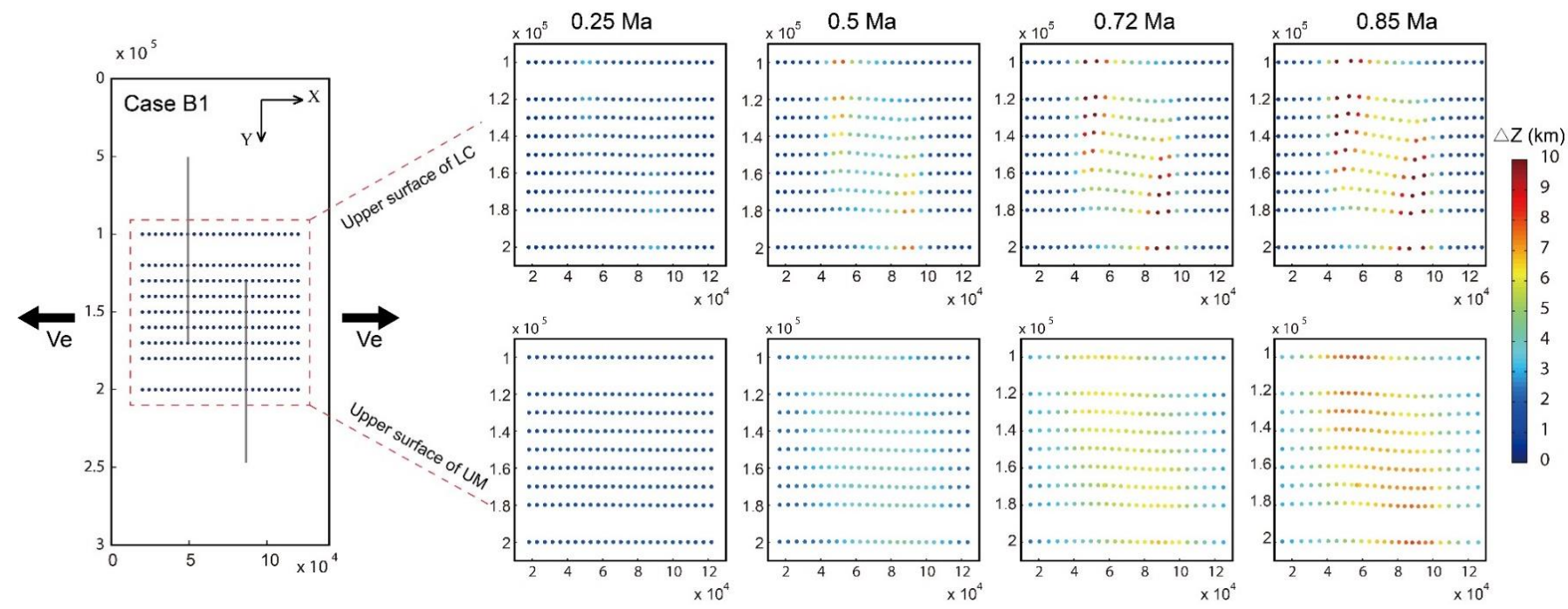

Figure 6. Model B1: evolution of migration of passive particles during extension. In left panel, the coordinate system is identical to Figure 3. The upper surfaces of the lower crust (LC, upper panel) and the upper mantle (UM, lower panel) contain 450 passive particles in total. The exhumation of passive particles is shown by the colour bar. Two pre-existing faults are indicated in black lines in left panel. Extension boundary conditions are indicated in black arrows. 
Solid Earth Discuss., https://doi.org/10.5194/se-2017-142

Manuscript under review for journal Solid Earth

Discussion started: 30 January 2018

(c) Author(s) 2018. CC BY 4.0 License.

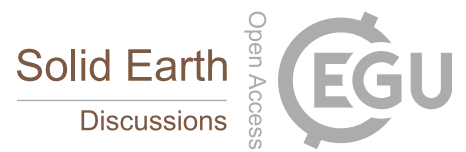

(c) (i)
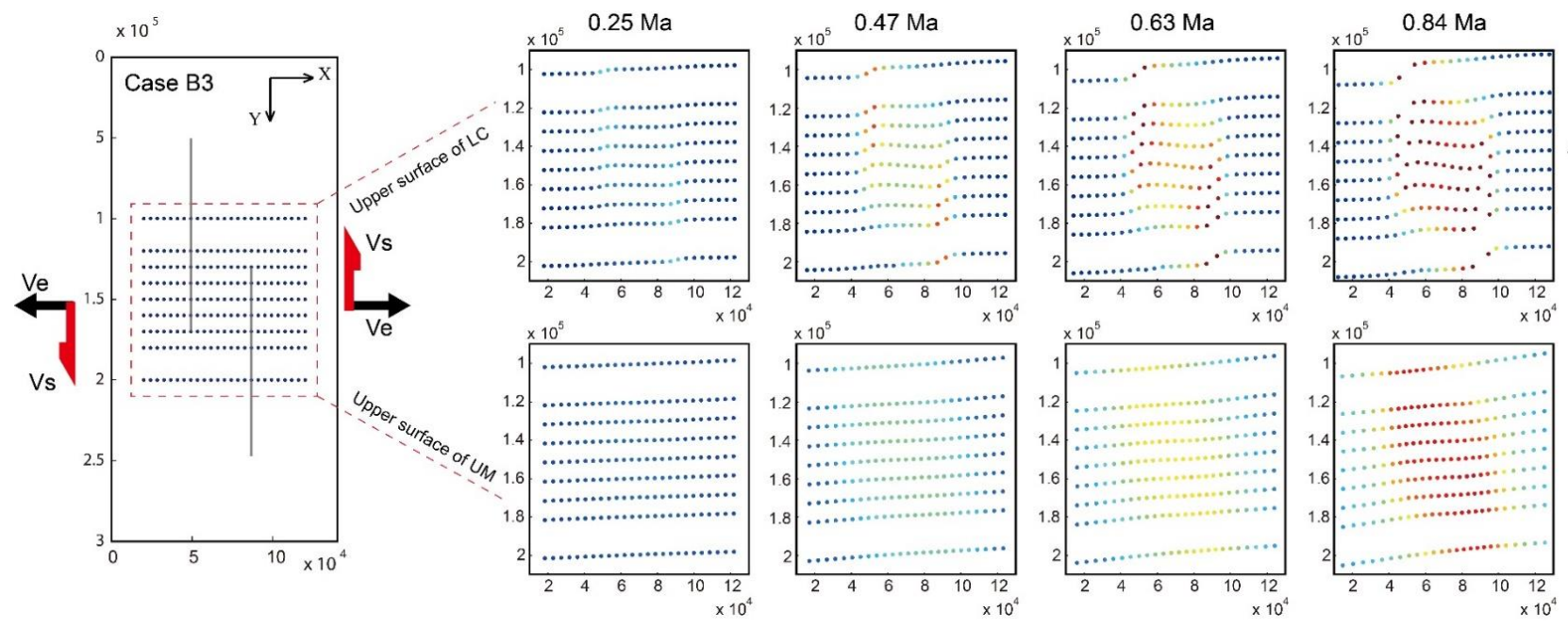

Figure 7. Model B3, migration of passive particles during transtension. In total of 450 particles divided into two groups are placed in the upper surfaces of the lower crust (LC) and the upper mantle (UM), respectively. The colour of passive particles represents the exhumation of the lower crust and the compensation from the upper mantle to the overlying crust during transtension. Two vertical faults are placed (black lines in left panel). Boundary

5 conditions are shown by red and black arrows. Vs and Ve with red and black arrows represent the rates and directions of shear and extension (see detailed parameters in Table 1), respectively. 
Solid Earth Discuss., https://doi.org/10.5194/se-2017-142

Manuscript under review for journal Solid Earth

Discussion started: 30 January 2018

(c) Author(s) 2018. CC BY 4.0 License.
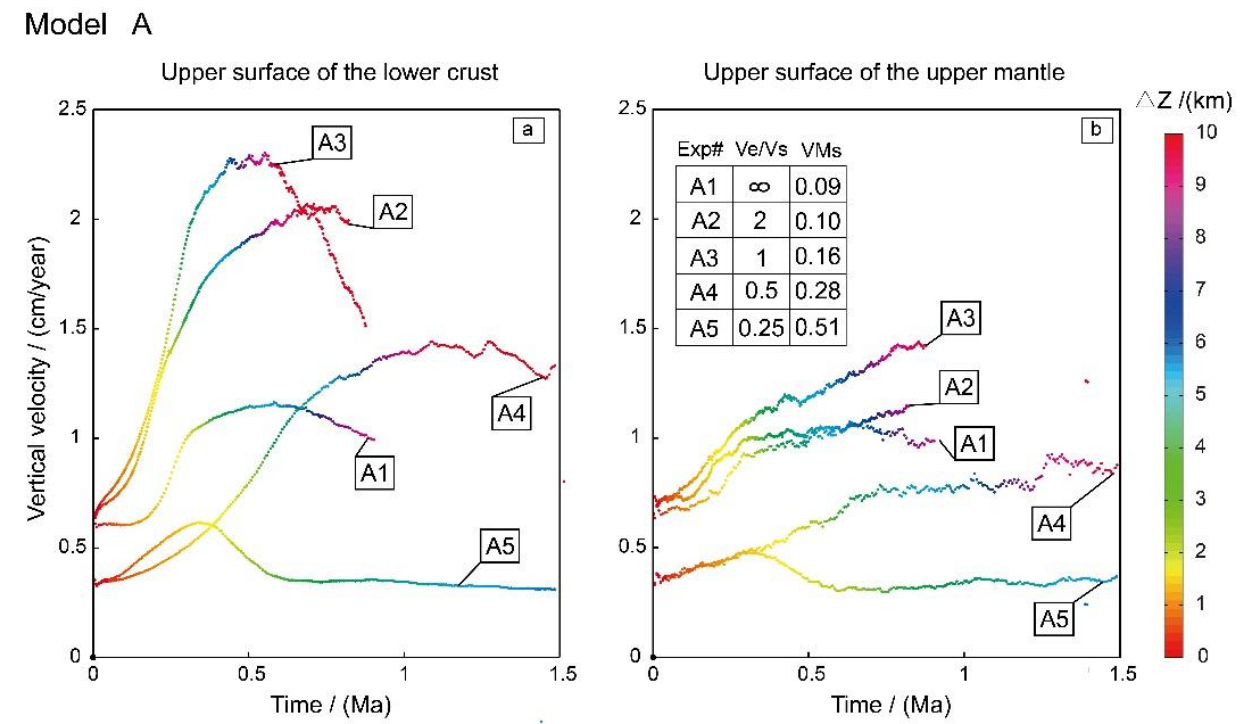

Figure 8. Model A. (a) Exhumation rate of the lower crust, (b) the isostatic compensation from the upper mantle to the overlying crust. The passive particles employed for plotting the left and right figures are located at $(\mathbf{7 0}, 150,-32)$ and $(70,150,-42)(X, Y, Z$ $/ \mathrm{km})$, respectively. The colour bar represents the accumulative height of exhumation over time. Exp\# is the name of experiment.

$5 \mathrm{Ve} / \mathrm{Vs}$ is the ratio of extension rate to shear rate applied on the boundaries. VMs represents the Von Mises equivalent strain. 
Solid Earth Discuss., https://doi.org/10.5194/se-2017-142

Manuscript under review for journal Solid Earth

Discussion started: 30 January 2018

(c) Author(s) 2018. CC BY 4.0 License.

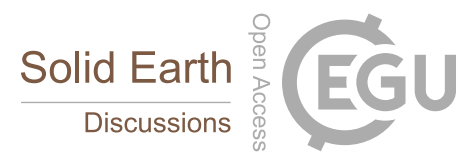

(c) (i)

Model B
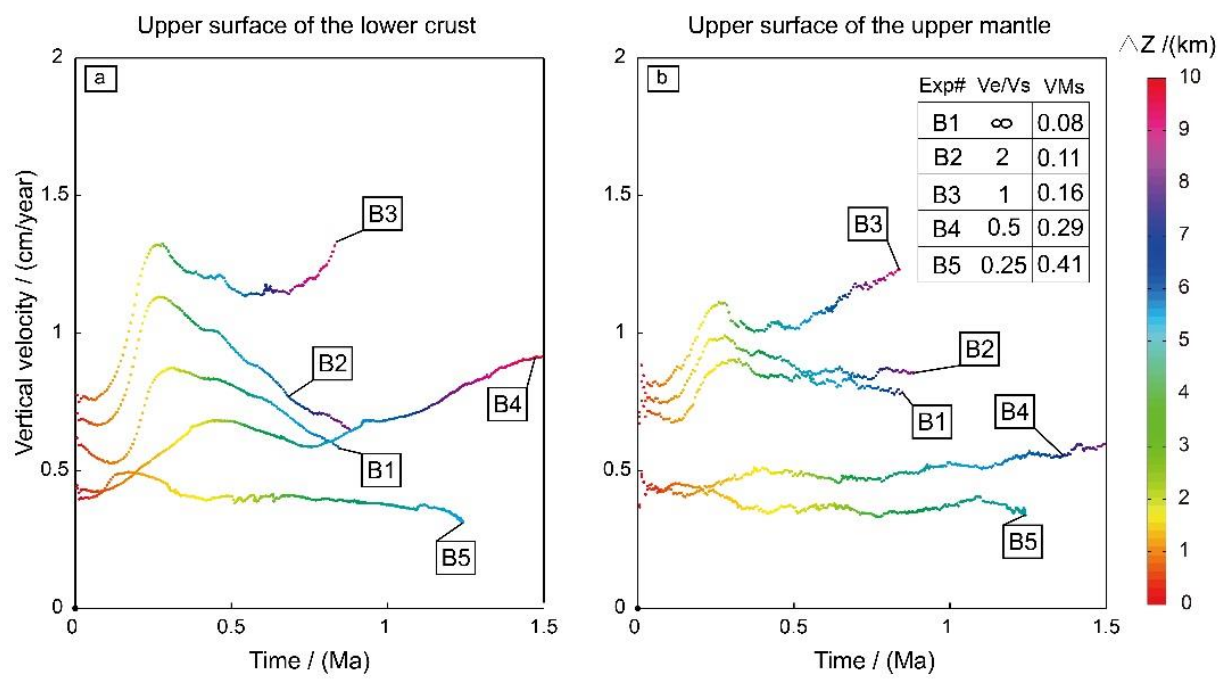

Figure 9. Model B. (a) Exhumation rate of the lower crust. (b) the isostatic compensation from the upper mantle to overlying crust. The passive particles employed for plotting (a) and (b) are located at $(70,150,-32)$ and $(70,150,-42)(/ \mathrm{km})$, pertaining to the upper surfaces of the lower crust and the upper mantle, respectively. 
Solid Earth Discuss., https://doi.org/10.5194/se-2017-142

Manuscript under review for journal Solid Earth

Discussion started: 30 January 2018

(c) Author(s) 2018. CC BY 4.0 License.

(c) (i)
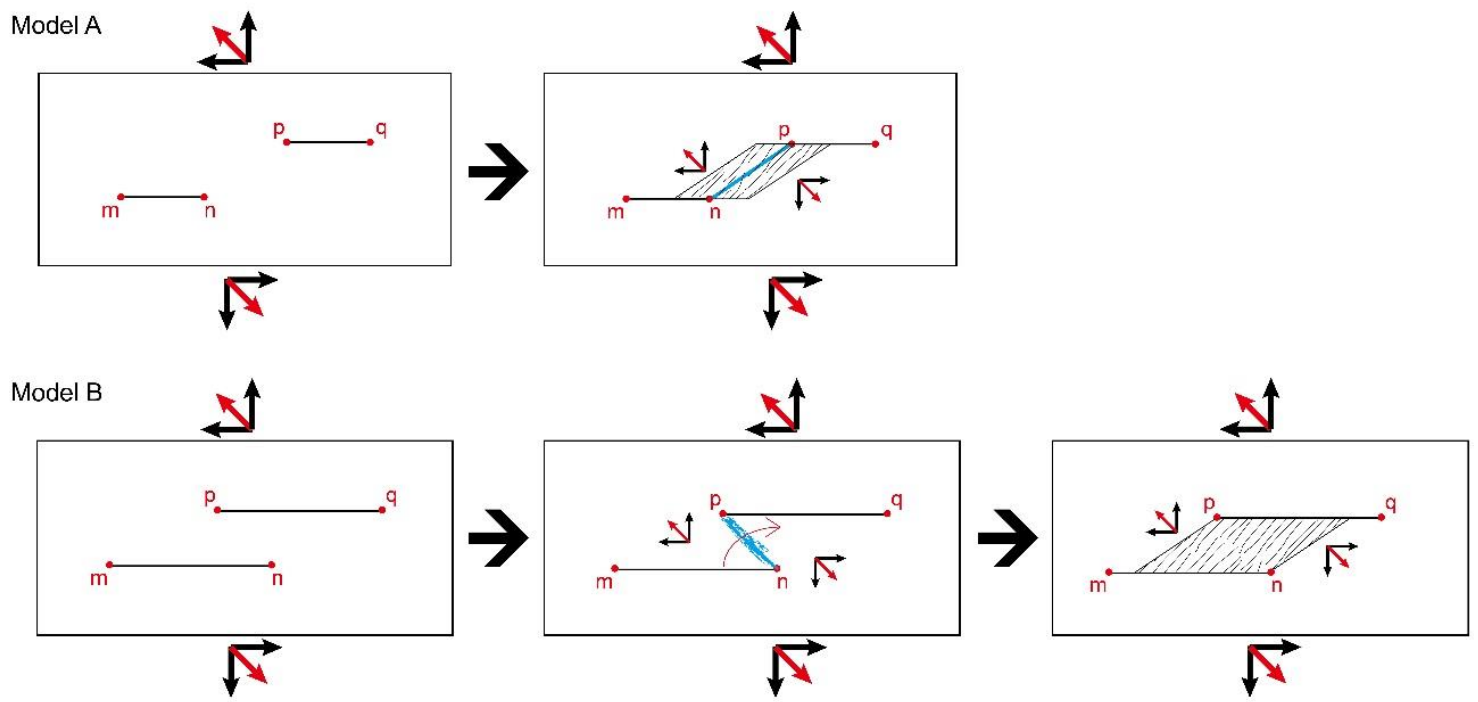

Figure 10. Conceptual models are constructed to explain the process of faults-related exhumation in the overlapping zone. The first column shows the initial geometry of pre-existing faults according to the numerical model setup (Model A and Model B, from Figure 3), m, n, p and $q$ are used to mark the tips of faults. Black arrows represent the applied extension and shear rates, red 5 arrows represent the equivalent direction of transtension. The middle and right columns represent the different stages of producing linking high strain zones driven by the external boundary conditions. 
Solid Earth Discuss., https://doi.org/10.5194/se-2017-142

Manuscript under review for journal Solid Earth

Discussion started: 30 January 2018

(c) Author(s) 2018. CC BY 4.0 License.

(c) (1)

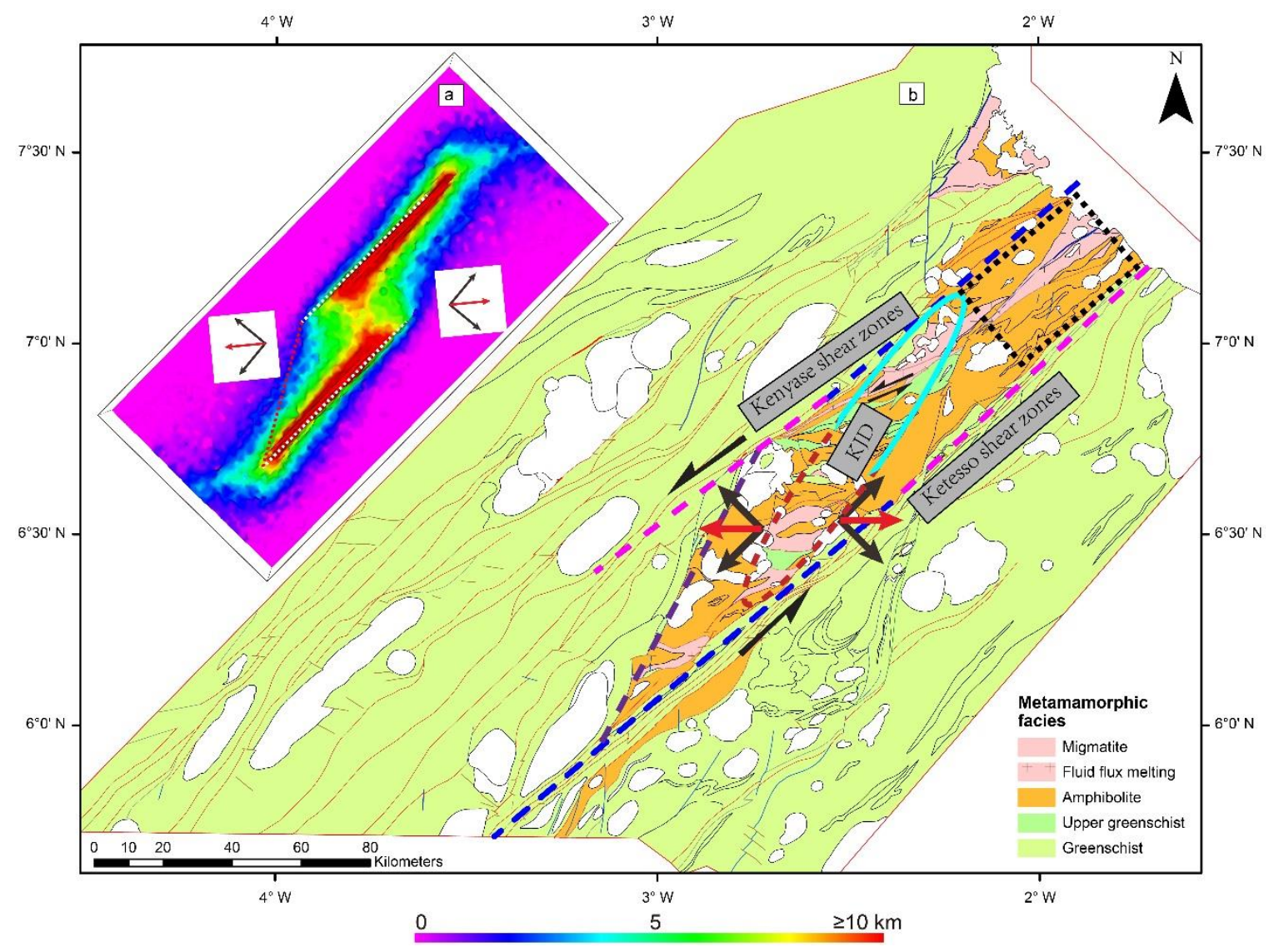

Figure 11. (a) The numerical results (case B3, Figure 4-B3) show the uplift of the upper surface of the partially molten lower crust (0-10km scale colour bar). (b) Metamorphic map in the Sefwi terrane modified after McFarlane et al. (2017). Transtension boundary conditions are indicated by red arrows. 